\title{
Beyond Chayanov: A Sustainable Agroecological Farm Reproductive Analysis of Peasant Domestic Units and Rural Communities (Sentmenat; Catalonia, 1860)
}

R. Padróa, ${ }^{*}$, I. Marco ${ }^{\mathrm{b}}$, C. Font ${ }^{\mathrm{c}}$, E. Tello ${ }^{\mathrm{b}}$

${ }^{\text {a }}$ Department of Ecology and Territory, Barcelona Institute of Regional and Metropolitan Studies, Autonomous University of Barcelona, 08193, Bellaterra, Spain

${ }^{\mathrm{b}}$ Department of Economic History, Institutions and Policy and World Economy, University of Barcelona, Faculty of Economics and Business, Av. Diagonal 690, 08034, Barcelona, Spain

${ }^{\mathrm{c}}$ Catalan Institute for Water Research, H2O Building, Emili Grahit 101, 17003, Girona, Spain.

* Corresponding author.

E-mail: roc.padro@ub.edu 


\section{Introduction}

Increasing food demand in a world subject to global environmental deterioration raises the challenge of designing more sustainable agricultural systems capable of maintaining food production within appropriate biophysical limits to guarantee ecological functions. At the same time, growing demands claim to relocate agri-food chains to improve the sustainability of agroecosystems (Sayer et al., 2013), and to rethink land-use planning and rural development programmes linked to nature conservation policies (Stoate et al., 2009). New plans and programmes aimed at tackling this current food-biodiversity dilemma require new indicators and models to combine all these dimensions and approaches, as well as the democratization of governance in order to implement effective solutions (Moragues-Faus and Morgan, 2015; Tello and González de Molina, 2017).

In recent decades, we have witnessed agroecosystems’ lack of sustainability with regards to energy and material efficiency losses which, in turn, has led to the increasing replacement of ecosystem services (soil fertility, pest and disease control) by industrial fossil-fuelled external inputs (Giampietro, 1997; Gliessmann, 1998; Leach, 1975; Pimentel et al., 1973). Behind current agricultural degradation and eco-inefficiencies (Cardinale et al., 2012; MEA, 2005; Padró et al., 2017) there are ideological constructs that concern the core of capitalism. Mainstream neoclassical economics considers land and labour only as production factors (Polanyi, 1944). However, when we do not consider them solely as commodities, we realise that they are neither static nor permanent resources, nor two variables of a production function isolated from one another. Ecological Economics is an alternative paradigm that attempts to return to an organic conception of labour, land and other natural resources by considering them as a living interrelated whole from a substantive and holistic perspective (Gerber and Scheidel, 2018; Gerber and Gerber, 2017).

Whether a resource is inanimate or living matters. As Georgescu-Roegen (1971) pointed out, the ultimate aim of agriculture is not only to produce useful biomass but also to reproduce the funds required to maintain the process. Therefore, in order to pursue its coproduction with Nature, agricultural systems have to account for the full costs of their own reproduction in biophysical terms 
(Guzmán et al., 2009; Van der Ploeg, 2014). In this regard, the approaches and methods of social metabolism are useful for shedding light on these multiple costs (Haberl et al., 2004).

Nonetheless, social metabolism is at a crossroads, facing two major challenges. First, there is a need to overcome stock-flow analysis by incorporating a fund-flow perspective that recognizes that coproduction with Nature requires reinvesting some specific biophysical flows to ensure the renewal of living funds (Gerber and Scheidel, 2017; Marco et al., 2017). Second, this requires an epistemological step forward to evaluate, integrate and model these fund-flow relationships to reorient agricultural policy, nature conservation and rural development plans (Zhang, 2013). Optimization analysis applied from a novel socio-metabolic and agroecological reproductive standpoint can be a useful tool for such sustainable farming design and land-use planning (Gabrel et al., 2014). To achieve these aims a meeting point between land-use planning and socio-ecological accounting of farming is needed. It is time for ecological economists to develop new optimization models that could identify feasible future scenarios based on what history and present best practices may teach us.

Modelling the functioning of agroecosystems from a reproductive standpoint opens the door for a deeper analysis of the joint functioning of organic farming and agricultural communities, either in past times or at present. We present here a Sustainable Agro-ecological Farm Reproduction Analysis (SAFRA) aimed at devising and planning more sustainable farms and agroecological territories (Wezel et al., 2016; González de Molina and Guzmán, 2017; Stoate et al., 2009; Tilman and Clark, 2014). This linear programming model allows the optimization of land-use distributions based on the need to reproduce three agroecosystem funds (the peasant community, livestock and farmland), by always keeping a set of interactions among them that take into account their biophysical and technological limits.

There are two proposals on which we set the foundations of this model, even though they differ significantly from each other. First, this study is connected with the internal planning of economic peasant units proposed by Chayanov ([1925]1985; Van der Pleog, 2014). Chayanov's theory of peasant economies began the development of reproductive studies of domestic farming units, by accounting for the amount and allocation of land required according to the components of the family 
farm, livestock density and cultural practices at stake. However, his approach combined only units of labour time, family needs, livestock intake and farm produce translated into a monetary budget driven by the effort-consumption balance. Here, we incorporate a biophysical dimension to ensure the simultaneous maintenance of a larger range of living funds, such as farmland reproduction (by assessing soil biogeochemical cycles).

Secondly, this research is related to food systems analysis. These studies use optimization analysis to identify the most appropriate distribution of land uses in order to satisfy diets from a local or regional perspective. They assess the impact of diets and the food supply capacity at the local level, within the framework of conventional agriculture, focusing on the consumption side. Although food systems research incorporates optimization analysis from a socio-ecological perspective (Desjardins et al., 2010; Meier and Christen, 2013; Peters et al., 2007; Van Kernebeek et al., 2016), it does not include a fund-flow analysis - i.e. it does not attempt to close the biophysical cycles of funds (Altieri and Nicholls, 2012; Wezel et al., 2016).

Other applications of optimization analysis in designing how to distribute land uses in agriculture are also well known, but so far its application has mainly been limited to monetary accounting (Knoke et al., 2015). Finally, some optimization analysis also appeared as tools to consider the effect of multifunctionality on land uses, although flux interactions among land uses are not been considered (Grabaum and Meyer, 1998; Meyer et al., 2009; Sadeghi et al., 2009; Seppelt and Voinov, 2003; Smit, 1981; Stewart et al., 2004).

As a first step in our research strategy, we modelled the agroecosystem functioning of a local case study before the Green Revolution through an exercise of Applied Environmental History based for the first time on a socio-metabolic optimization model. In this regard, the study of past organic agrarian societies, just before agrarian capitalism fully developed, has two advantages. First, the methodology is much simpler compared to current agro-industrial systems, which depend heavily on external nonrenewable resources. Second, the results obtained with this interesting analysis transcend purely historical interests. 
Such agrarian economies were still driven by an advanced organic metabolism, where feasible biophysical intensification was mainly restricted to the local or regional level. This led farmers to maintain the integration among the different compartments of the agroecosystems, imprinting complex agrosilvopastoral mosaics in the territory (Antrop, 2005; Fischer-Kowalski and Haberl, 2007; Krausmann, 2004; Marull et al., 2016, 2010). Specialization processes via cash crops tended to push such agricultural systems towards their biophysical limits, and even to disrupt them through degradation processes. Thus, studying past organic farm systems offers useful information on the strategies used by farmers to meet the reproductive needs of all living funds (Tello and González de Molina, 2017; Tittonell, 2014), which could be useful references for developing a new sustainable farm metabolism today.

Although the main objective of this study is the theoretical, conceptual and mathematical definition of the SAFRA model, secondary objectives are pursued by applying it to a past organic agricultural system. First, we look for the multiple synergies and trade-offs which only arise by considering the funds' reproduction altogether compared with working them in isolation. Second, we investigate how farming strategies were aimed at satisfying contrasting goals that led to different funds' composition and reproduction.

In the second section we outline the conceptual approach used to study a past advanced organic agricultural system. The third section describes the features of the local case study. The fourth presents the methodology of our socio-metabolic optimization model. After running the model, the fifth section presents the results. Then, in the sixth we compare the scenarios obtained with the actual distribution of land uses by every farm in the case study, and to other Chayanovian models. We conclude in the seventh section by outlining the main findings and conclusions regarding the methodology and the functioning of advanced organic management of agroecosystems. 


\section{Conceptual development of the Sustainable Agroecological Farm Reproductive Analysis}

(SAFRA)

\subsection{A socio-metabolic model for agroecosystems’ reproductive functioning}

In order to improve agroecosystem planning, a new modelling approach is needed to tackle the auto-reproducible funds of farm systems. This means understanding how land, labour and natural resources can be de-commodified and sustainably managed within their own constraints. Funds are understood as those 'elements that are part of a process, which provide services for a certain period but are never physically incorporated in the product', as defined by Georgescu-Roegen (1971). Specifically, those of a biological basis are auto-reproducible funds whose maintenance requires regularly reinvesting a certain amount of the biomass taken from the agroecosystem. Disregarding either the limits in the rate and volume of extraction or in the reinvestment required means jeopardizing the agroecosystems’ sustainability (Giampietro et al., 2013).

We will consider three main funds: farmers' domestic units, livestock and farmland. The model identifies the conditions required to reproduce them in a specific territory over the timescale of one year. For example, farmers need to maintain their workforce to sustain the flow of labour, which entails two basic material conditions: provision of enough food and fuel, and not exceeding their own work capacity. The same applies to livestock and farmland (the latter assessed through biogeochemical cycles but also based on its capabilities in terms of soil quality or irrigated land). These biophysical constraints, each measured using different meaningful values, determine the range of feasible and technically viable farms that could have existed under the prevailing site-specific historical and biogeographical context.

In this way, the optimization model generates simulated scenarios, either in the past as counterfactual analysis or in the future as prospective scenarios, in a controlled process that integrates all the relevant constraints that ensure the socio-ecological reproduction of funds. The modelling degrees of freedom guarantees that results would be technically viable and agroecologically feasible, avoiding ceteris paribus assumptions as the model considers the simultaneous interactions that always take place among the main dimensions modelled. When applying this SAFRA model, and considering 
the joint reproduction needs and capacities of all these funds, we can identify the potential synergies and trade-offs that arise when they are managed in an integrated manner, and thus determine the composition that optimizes their functioning under a specific goal in a site-specific context.

\subsection{How social agencies constrain fund distribution}

The biophysical factors considered to date define only the range of possibilities and limits within the agroecosystem e.g. its land-use and labour intensification capacities in a given context. However, land appropriation deeply affected its use and the ensuing organization of farm labour, which entailed other kinds of ruling forces. In addition, we are aware of the difficulties of defining the territorial boundary of an agroecosystem, as there were exchanges of biophysical flows with other areas, and with non-farming social groups. Because of this, to develop a more reliable approach from a societal and institutional perspective, we will consider agroecosystem functioning at the farm-gate and community-level scale simultaneously (Bayliss-Smith, 1982; Gerber and Scheidel, 2018; GizickiNeundlinger et al., 2017; Gizicki-Neundlinger and Güldner, 2017; Marco et al., n.d.). This would allow us to understand how agroecosystems could have been optimized under equal access to land, both for domestic units and at municipality level (as the composition of the whole community included different types of domestic units). From a socio-metabolic perspective we have identified three main categories relevant to land-use allocation in farm planning, similarly to the way in which Cronon (1991) defined the 'first and second nature' constraints: i) biophysical constraints (nature-nature relations), including biotic and abiotic factors present in the farm units; ii) cultural factors (naturesociety relations), such as the set of technologies and management approaches available in a sitespecific context; and iii) the prevailing social conditions (relations among people), including all societal constructions (institutional, economic, political or cultural) that affect agricultural practices. Distinguishing between ii and iii allows counterfactual analysis by identifying how the relations among people (iii) affect farm decisions and agricultural development by assuming the potential agricultural practices determined by the cultural and biogeographic context. Therefore, we have adopted herein a counterfactual analysis in the same way as in economic history (Cartwright, 2007; 
Fogel, 1964; North, 1961), but by assessing the underlying constraints and relationships through biophysical analysis.

\section{Case study: Sentmenat (Catalonia, Spain) c. 1860, a region specializing in vine growing at the dawn of agrarian capitalism}

We tested our SAFRA model in the context of an advanced organic agricultural system in the municipality of Sentmenat (Catalonia, Spain), which circa 1860 partially specialized in vine growing. A vast amount of socio-metabolic research has been carried out on this case study (Cussó et al., 2006; Galán et al., 2017, 2016, 2012; Garrabou et al., 2010, 2008, Marull et al., 2016, 2010; Olarieta et al., 2006; Tello et al., 2016, 2012), providing a large and reliable database on the composition of funds and flows at that time (for further details, see section 4.4).

Sentmenat is located on the tectonic boundary between the Vallès plain and the Catalan pre-littoral mountain range. It covers 2,880 ha with wide topological, geological and soil diversity under a subhumid Mediterranean littoral climate. Rainfall varies between 600 and 800 mm per year, increasing with altitude (Rodriguez Valle, 2003). Figure 1 shows how c. 1860 vines coexisted with dryland polycultures and woods, forming agricultural, pasture and forest mosaics. Population density was 60 inhabitants $/ \mathrm{km}^{2}$ which, according to Badia-Miró and Tello (2014), fitted the optimal demographic conditions for vineyard specialization. Vineyards covered $42 \%$ of the total surface area (72\% of cropland), and produced some $17,000 \mathrm{hl}$ of wine a year. Although there is no data on vineyard surface area for 1890, when it reached its peak, we know that wine production had increased up to 26,000 hl (Planas, 2015) by the time the Phylloxera plague started destroying French vines in the 1860s and ended up devastating those of the Valles in the late 1880s. Very few vineyards recovered from this devastating disease in the study area (Badia-Miró et al., 2010).

Importantly, until 1860 the agroecosystem functioning of Sentmenat was mainly restricted to the regional level from the reproductive view of its funds' maintenance. Local food and firewood needs were still largely met at the regional level (Padró et al., 2017), while livestock requirements and soil fertility maintenance were met at the local level. However there were also links to international 
Atlantic markets (for wine exports) and to the inner Iberian Peninsula (for wheat imports). As well, the land entitlements that prevailed in the transition from feudalism to agrarian capitalism, and the ensuing social polarization between wealthy landowners and small vine-growing tenants and labourers, played a major institutional role in this Catalan rural community (Garrabou et al., 2008, 2010; Congost et al., 2015).

Figure 1. Land uses in Sentmenat circa 1860. Source: Our own.

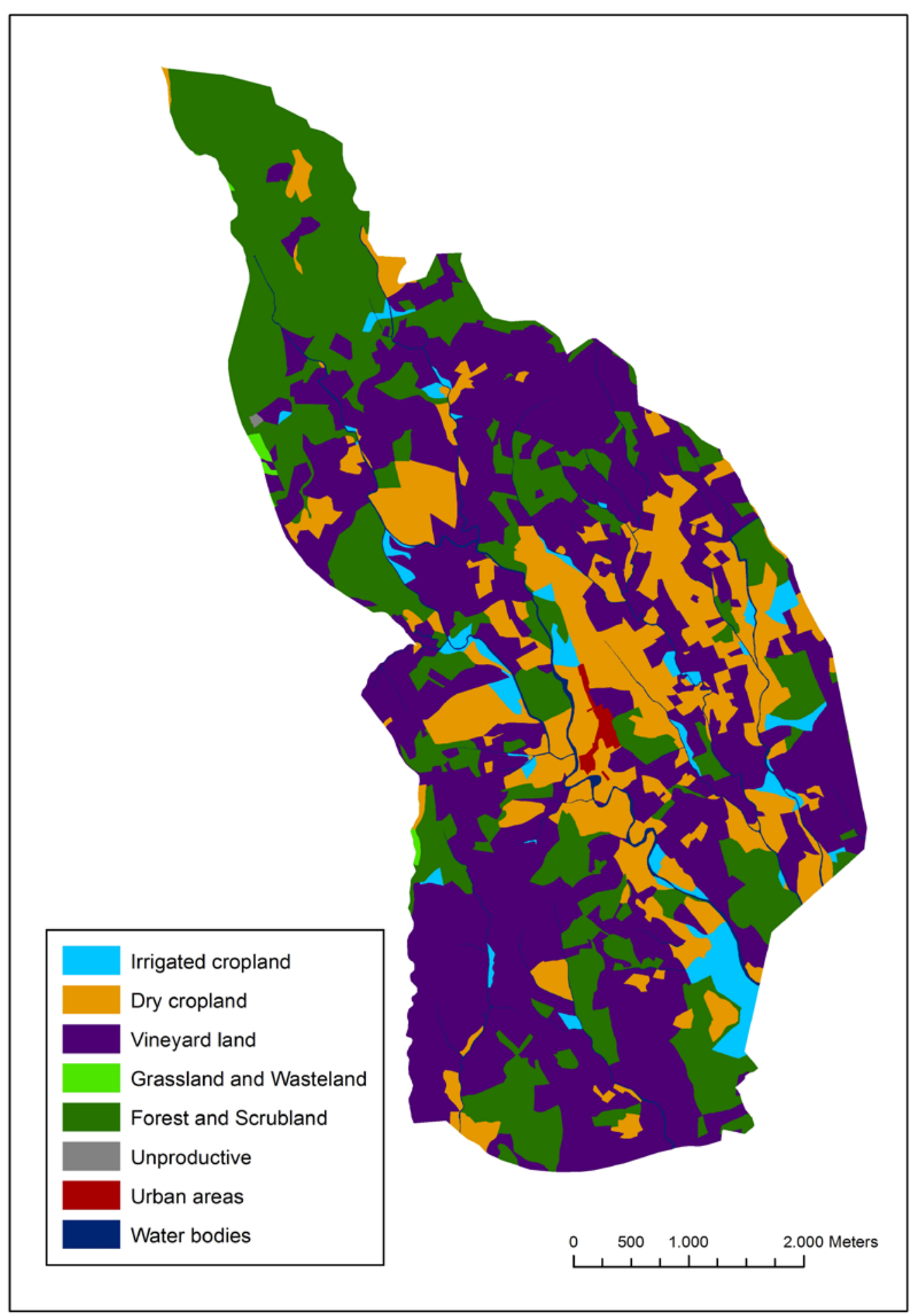




\section{Methodology 1}

\subsection{General structure of the model}

We developed the socio-ecological model based on the ability of farmers and communities to reproduce their basic funds under the prevailing natural and technical endowments from a fund-flow approach (Mayumi, 1991). The funds considered were, as mentioned: domestic units (DU), livestock, and farmland. Using the optimization model we accounted for the multiple interactions (flows) among these three funds in a way that might allow for their reproduction while reaching different optimality when satisfying a set of alternative specific goals (Figure 2).

Figure 2. Modelling diagram. Source: our own. Squares represent funds and arrows the flows interlinking them. Grey arrows are fluxes constrained as boundary conditions, while black ones are the restrictions calculated with the optimization model. Discontinuous lines emphasize the objective functions to optimize.

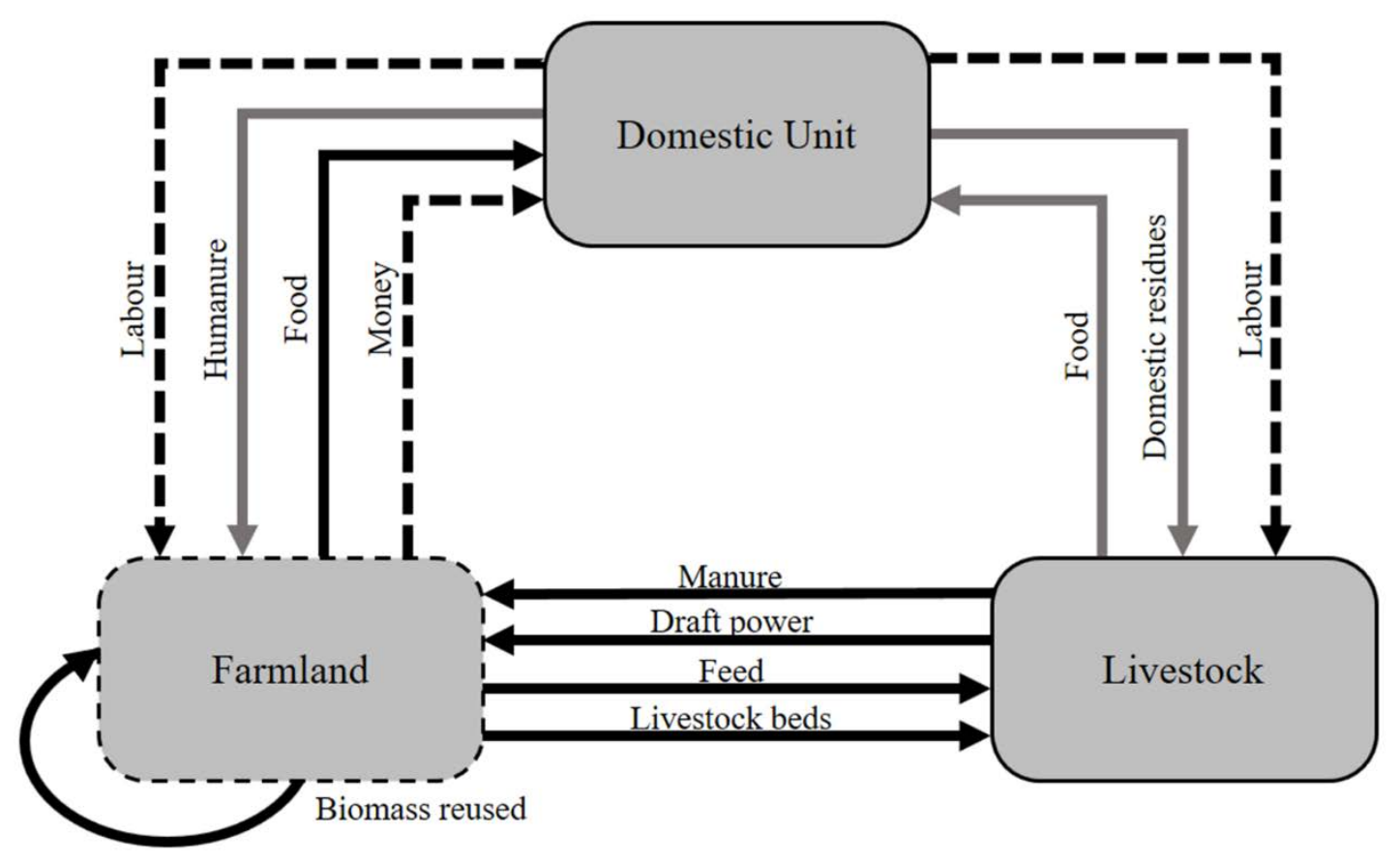

The mathematical procedure for running the optimization model is linear programming. This method achieves the best result by maximizing or minimizing (optimizing) first-degree functions, allowing infinite variables and linear constraints. Once the model is defined, it is run through the

\footnotetext{
${ }^{1}$ See Supplementary materials for further details
} 
Simplex algorithm programmed using the Java software Gusek (Bettoni, 2009; Dantzing, 1963). The model comprises main variables (22), secondary variables (128), parameters (3), general constraints (187), specific constraints (68) and objective functions (3). This structure allows for three different kinds of scenario, one for each objective function.

The modelling of all these constraints defines the range of agroecologically feasible and technically viable scenarios (as it ensures the reproduction of all the funds considered under the prevailing cultural practices in the historical and edaphoclimatic context).

As its main function is to define the structure of flows and funds in the agroecosystem, in this sitespecific context the number of constraints, variables and parameters would be different for each particular goal adopted. This is because the potential fluxes among funds will depend on the kind of cultural practices that could be available and desirable (livestock types, crop rotations, fertilization practices, etc.).

\subsection{Boundary conditions}

In order to calculate its size a fund should have to optimize a given goal in a sustainable way, and we considered the size of the other two funds as boundary conditions. This involves checking whether livestock density changes would increase the efficiency of resource allocation in the different scenarios.

We started the process by defining the size and composition of the domestic unit (DU), which entails an important decision that affects the interpretation. The representative family selected supposes a rate of consumers/producers consistent with the average dependence rate of the whole municipality, so as to allow us to extrapolate the DU results at the local level. Indeed, following Chayanov ([1925]1986), we also included five different stages of the family life cycle of this representative DU in order to determine how requirements would change over time, and to avoid underestimating or overestimating the results. 
Our representative DU of five people (the average family type in Sentmenat c. 1860) comprised a girl between 0-5 years old, a boy from 5-10 years old, a woman and a man between 18 and 60 years old, and a man older than 60 .

\subsection{Variables, general constraints and parameters}

The main variables, from $X_{1}$ to $X_{22}$, represent the surface area of each land use (see Table 2), although in the programming they were divided by soil quality (including new variables from $X_{23}$ to $\left.X_{41}\right)$. Secondary variables regarding fluxes were as follows: $X$-secondary variables $\left(X_{i, j, k}\right)$ are the fraction of embedded land in the biomass produced by a land use $i$, and a kind of product or by-product $j$ used in a human activity $k$; and $Y$-secondary variables $\left(Y_{l, m, n}\right)$, which do not represent land but fluxes from another fund $l$, a kind of product $m$ used in a human activity $n$. Therefore, there are as many secondary variables as directions flows could take. This supposes, in turn, two kinds of general constraint: i) each variable must be a positive number; ii) every group of secondary variables is associated with the total amount of land $\left(X_{i}\right)$ or biomass coming from livestock or the DU $\left(Y_{l}\right)$.

As pointed out in section 4.2, the dimensions of DU and livestock heads are boundary conditions. We thus defined a parameter $Z$ that represents the integer number of members in the farm unit. Small livestock numbers depend on the size of the DU (Z), while draught animals depend on the cropping surface through another parameter $M$, representing its density.

\subsection{Specific constraints and data sources}

All variables are subject to a number of biophysical constraints expressed by linear inequalities. These constraints are imposed by the conditions required for the agroecosystem reproduction, ranging from obtaining enough food, fuel and money, to feeding livestock and closing the soil biogeochemical cycles, while maintaining the historically prevailing crop rotations. We defined the minimum and maximum feasible ranges of flows for the three funds, which would allow each of them to ensure agroecological reproducibility (minimum for inputs, and maximum for outputs of the fund). Table 1 summarizes the main aspects considered in the optimization model, from which constraints were 
derived. Regarding DU consumption, we considered basic human material needs as being determined ex-ante, and did not consider the improvement of farmers' well-being (Harrison, 1975). Given that we wished to set a threshold for farming family reproduction, and not for how to organize a farm with abundant means of production, we consider this demand to be inelastic. 
Table 1. Constraints and main sources considered in the programming model..

\begin{tabular}{|c|c|c|c|c|}
\hline Fund & $\begin{array}{l}\text { Main } \\
\text { flow }\end{array}$ & $\begin{array}{c}\text { Associate } \\
\text { d funds }\end{array}$ & Units & Procedure \\
\hline \multirow{4}{*}{ 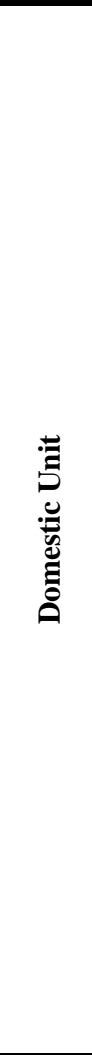 } & Labour & $\begin{array}{l}\text { Farmland, } \\
\text { Livestock }\end{array}$ & Workdays & $\begin{array}{l}\text { Twelve inequalities with human monthly requirements of } \\
\text { labour for crops, forest and livestock (Garrabou et al., 1992; } \\
\text { IACSI, 1879) on the one hand, and the working capacity of } \\
\text { the DU on the other (Marco et al., n.d.) }\end{array}$ \\
\hline & Food & $\begin{array}{l}\text { Farmland, } \\
\text { Livestock }\end{array}$ & $\begin{array}{l}\text { Kg of fresh } \\
\text { matter }\end{array}$ & $\begin{array}{l}\text { Eight inequalities, one for each main product typology in the } \\
\text { diet (wheat, legumes, olive oil, etc.), where production must } \\
\text { be higher than requirements, calculated from the typical diets } \\
\text { in the region in the mid- } 19^{\text {th }} \text { century (Cussó and Garrabou, } \\
\text { 2012) }\end{array}$ \\
\hline & Fuel & Farmland & $\begin{array}{l}\text { Kg of fresh } \\
\text { matter }\end{array}$ & $\begin{array}{l}\text { Inequality considering the need for fuelwood from forest and } \\
\text { woody crops in order to cook and heat the house, based on a } \\
\text { review of sources (Marco et al., forthcoming). Inequality } \\
\text { limiting the use of vine-wood according to its low latent } \\
\text { heating (Colomé, 2016; personal communication) }\end{array}$ \\
\hline & Money & $\begin{array}{l}\text { Farmland, } \\
\text { Livestock }\end{array}$ & Pesetas & $\begin{array}{l}\text { Inequality to ensure enough money for the reproduction } \\
\text { expenses coming from other Catalan Chayanovian- } \\
\text { reproductive studies. We considered costs relating to clothing } \\
\text { and footwear (Colomé, 2015), the rent for housing (Colomé, } \\
1996 \text { and Vicedo et al., 2002), and the amortization cost of } \\
\text { farm implements and the maintenance of barrels for wine } \\
\text { producing (Colomé, 1996). We also considered the costs of } \\
\text { paying the royal land, housing and livestock cadastral taxes, } \\
\text { as well as the municipal taxes according to the Distribution of } \\
\text { Personal Wealth in Real Estate Ownership of } 1852 \text { in the } \\
\text { Barcelona Province (Library of the University of Barcelona, } \\
\text { reference 146-1-II/13). All these costs must be lower than the } \\
\text { surplus produced via farm sales in the local market, assessed } \\
\text { through the prices given in the Estudio Agrícola del Vallès } \\
\text { (Garrabou and Planas, 1999) }\end{array}$ \\
\hline \multirow{3}{*}{ 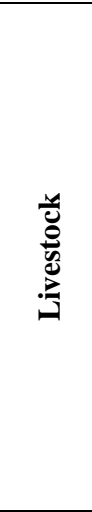 } & Feed & $\begin{array}{l}\text { Farmland, } \\
\text { Domestic } \\
\text { Unit }\end{array}$ & $\begin{array}{l}\text { Metabolizable } \\
\text { energy }\end{array}$ & $\begin{array}{l}\text { Six inequalities, one for each species of livestock (sheep, } \\
\text { mule, hens, etc.), in order to ensure enough metabolizable } \\
\text { energy to meet their requirements (assessed by Church, } \\
\text { 1984), through the consumption of products and by-products } \\
\text { from farmland and domestic residues as well. We also } \\
\text { introduced five more inequalities to guarantee that feed ratios } \\
\text { were reasonable based on animal physiology criteria } \\
\text { (FEDNA, 2010). }\end{array}$ \\
\hline & $\begin{array}{c}\text { Stall } \\
\text { bedding }\end{array}$ & Farmland & $\begin{array}{l}\text { Kg of fresh } \\
\text { matter }\end{array}$ & $\begin{array}{l}\text { Inequality ensuring that by-products used for stall bedding } \\
\text { (straw and stalks) were suitable for the animal beds (Cascón, } \\
\text { 1918; Soroa, 1953) }\end{array}$ \\
\hline & $\begin{array}{l}\text { Draft } \\
\text { power }\end{array}$ & Farmland & Workdays & $\begin{array}{l}\text { Inequality where total amount of labour required for cropping } \\
\text { practices has to be lower than the available workdays from } \\
\text { draught animals (Garrabou et al., 1992; IACSI, 1879) }\end{array}$ \\
\hline \multirow{4}{*}{ 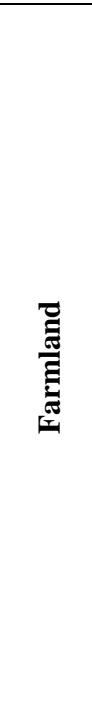 } & $\begin{array}{l}\text { Soil } \\
\text { biogeoch } \\
\text { emical } \\
\text { cycles }\end{array}$ & $\begin{array}{l}\text { Domestic } \\
\text { Unit, } \\
\text { Livestock }\end{array}$ & $\begin{array}{l}\text { Kg of } \\
\text { nitrogen, } \\
\text { phosphorus } \\
\text { and potassium }\end{array}$ & $\begin{array}{l}\text { Fifteen inequalities (five land covers and three nutrient } \\
\text { balances for each nutrient) assuming that biogeochemical } \\
\text { fluxes are closed at the farm level using humanure, animal } \\
\text { manure and burying biomass (from cropped areas but also } \\
\text { from forests). Nutrient balances were calculated following } \\
\text { González de Molina et al. (2010), composition of humanure } \\
\text { according to Gootas (1956), manure according to the ASAE } \\
\text { (2000) and the nutrient composition of biomass according to a } \\
\text { previous meta-analysis (Galán et al., 2016; Guzmán et al., } \\
\text { 2014; Tello et al., 2012). }\end{array}$ \\
\hline & $\begin{array}{c}\text { Soil } \\
\text { qualities }\end{array}$ & & Hectares & $\begin{array}{l}\text { Two inequalities ensuring that fractions of soil qualities I and } \\
\text { II (there are III in total) are not higher than the total share at } \\
\text { the municipal level according to the cadastre. }\end{array}$ \\
\hline & $\begin{array}{l}\text { Crop } \\
\text { rotations }\end{array}$ & & Hectares & $\begin{array}{l}\text { Fifteen equations, four for irrigated land, five for herbaceous } \\
\text { dryland and six for herbaceous grains intercropped with olive } \\
\text { trees, in order to reproduce the same rotations described in the } \\
\text { Estudio Agrícola del Vallès. }\end{array}$ \\
\hline & $\begin{array}{l}\text { Irrigated } \\
\text { land }\end{array}$ & & Hectares & $\begin{array}{l}\text { Inequality constraining the total surface area of irrigated land } \\
\text { to the same share recorded in the municipality c. } 1860 \text { in the } \\
\text { cadastre. }\end{array}$ \\
\hline
\end{tabular}

Sources: See the right column. 
The data used to set the constraints was based on an array of documentary sources such as the Population Census, Cadastral Map, and Land-Use Register (Amillaramiento). The Estudio Agrícola del Vallès (Garrabou and Planas, 1998), a manuscript written in 1874 that provides a detailed description of the common agrarian practices performed, their frequency and their distinct local specificities, was also fundamental as contains in-depth knowledge on the agrarian metabolism in this area. Data on yields by land-use, soil quality and rotations given in the Amillaramiento was a 5-year average to avoid inadvertently selecting an extreme-weather year (Table 2). These sources ensured the quality of the data used in the model, which has been reinforced through multiple cross-checking done by the many researchers who have used this case study as a test bench (Cussó et al., 2006; Galán et al., 2017, 2016, 2012; Garrabou et al., 2010, 2008, Marull et al., 2016, 2010; Olarieta et al., 2006; Tello et al., 2016, 2012).

Regarding data on the technical coefficients required to turn fresh weights into dry weights, energy and nutrient contents according to the composition of each biomass flow, we took advantage of several meta-analyses conducted within the international project Sustainable Farm Systems, and others that have standardized from a historical point of view the nutrients and moisture of products and byproducts, livestock and human requirements and manure amounts and compositions detailed in Table 1. 
Table 2. Registered land productivity and estimated by-products according to soil quality (SQ), in kg/ha, fund direction of flow and main variable in parenthesis. DU indicates Domestic Unit, L to livestock and F for farmland. Source: our own.

\begin{tabular}{|c|c|c|c|c|c|c|}
\hline & $\begin{array}{c}\text { Crop or land use (main } \\
\text { variable) }\end{array}$ & Product & SQ1 & SQ2 & SQ3 & Direction \\
\hline \multirow{6}{*}{ 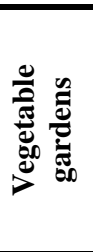 } & \multirow{2}{*}{ Vegetables $\left(\mathrm{X}_{1}\right)$} & Vegetables & \multicolumn{2}{|c|}{5,070} & & $\mathrm{DU}$ \\
\hline & & Straw & & 5,342 & & $\mathrm{~L}$ \\
\hline & \multirow{2}{*}{ Fresh fruits $\left(\mathrm{X}_{2}\right)$} & Fruits & & 4,148 & & $\mathrm{DU}$ \\
\hline & & Firewood & & 2,475 & & DU \\
\hline & \multirow{2}{*}{ Nuts $\left(X_{3}\right)$} & Dry fruits & \multicolumn{2}{|r|}{525} & & $\mathrm{DU}$ \\
\hline & & Firewood & \multicolumn{3}{|c|}{2,847} & DU \\
\hline \multirow{8}{*}{ 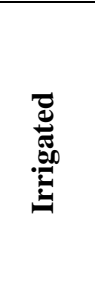 } & \multirow{2}{*}{ Wheat $\left(\mathrm{X}_{4}\right)$} & Grain & 1,242 & 1,023 & 731 & DU \\
\hline & & Straw & 2,889 & 2,433 & 1,825 & $\mathrm{~L}+\mathrm{F}$ \\
\hline & \multirow{2}{*}{$\operatorname{Corn}\left(\mathrm{X}_{5}\right)$} & Grain & 1,348 & 1,075 & 802 & $\mathrm{~L}$ \\
\hline & & Stalks & 1,044 & 835 & 627 & $\mathrm{~L}$ \\
\hline & \multirow{2}{*}{$\operatorname{Hemp}\left(\mathrm{X}_{6}\right)$} & Fibre & 1,213 & 1,104 & 996 & DU \\
\hline & & Stalks & 1,477 & 1,354 & 1,231 & $\mathrm{~L}$ \\
\hline & \multirow{2}{*}{ Beans $\left(\mathrm{X}_{7}\right)$} & Beans & 1,078 & 853 & 640 & $\mathrm{DU}+\mathrm{L}$ \\
\hline & & Straw & 1,695 & 1,378 & 1,060 & $\mathrm{~L}$ \\
\hline \multirow{19}{*}{ 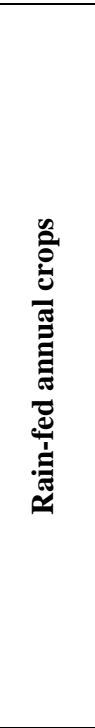 } & \multirow{2}{*}{ Wheat $\left(\mathrm{X}_{8}\right)$} & Grain & 1,169 & 877 & & DU \\
\hline & & Straw & 2,737 & 2,129 & & $\mathrm{~L}+\mathrm{F}$ \\
\hline & \multirow{2}{*}{ Associated wheat $\left(\mathrm{X}_{9}\right)$} & Grain & 877 & & & DU \\
\hline & & Straw & 1,521 & & & $\mathrm{~L}+\mathrm{F}$ \\
\hline & \multirow{2}{*}{ Corn $\left(X_{10}\right)$} & Grain & & 501 & & $\mathrm{~L}$ \\
\hline & & Stalks & & 783 & & $\mathrm{~L}$ \\
\hline & \multirow{2}{*}{ Rye \& wheat mixture $\left(\mathrm{X}_{11}\right)$} & Grain & & 424 & 636 & DU \\
\hline & & Straw & & 1,176 & 1,617 & $\mathrm{~L}+\mathrm{F}$ \\
\hline & \multirow{2}{*}{ Barley $\left(\mathrm{X}_{12}\right)$} & Grain & & & 439 & $\mathrm{~L}$ \\
\hline & & Straw & & & 1,096 & $\mathrm{~L}+\mathrm{F}$ \\
\hline & Fodder $\left(\mathrm{X}_{13}\right)$ & Fodder & & 6,754 & & $\mathrm{~L}$ \\
\hline & \multirow{2}{*}{ Potatoes $^{2}\left(\mathrm{X}_{14}\right)$} & Potatoes & $1,679 / 1,250$ & 1,215 & & DU \\
\hline & & Straw & $1,020 / 784$ & 765 & & $\mathrm{~F}$ \\
\hline & \multirow{2}{*}{ Beans $\left(\mathrm{X}_{15}\right)$} & Beans & 658 & & & $\mathrm{DU}+\mathrm{L}$ \\
\hline & & Straw & 1,060 & & & $\mathrm{~L}+\mathrm{F}$ \\
\hline & \multirow{2}{*}{ Vetches $\left(\mathrm{X}_{16}\right)$} & Vetches & & & 658 & $\mathrm{~L}$ \\
\hline & & Straw & & & 954 & $\mathrm{~L}+\mathrm{F}$ \\
\hline & \multirow{2}{*}{ Lupins $\left(\mathrm{X}_{17}\right)$} & Lupins & & & 585 & $\mathrm{~L}$ \\
\hline & & Straw & & & 954 & $\mathrm{~L}+\mathrm{F}$ \\
\hline & & Olive oil & 273 & 202 & 141 & DU \\
\hline & & Browsing & 796 & 590 & 413 & $\mathrm{~L}$ \\
\hline อิ & Olives $\left(X_{18}\right)$ & Pomace & 1,205 & 893 & 625 & $\mathrm{~L}$ \\
\hline ن & & Firewood & 1,628 & & & $\mathrm{DU}+\mathrm{F}$ \\
\hline 궁 & & Grape juice & 2,142 & 1,683 & 918 & DU \\
\hline$\sum_{2}^{8}$ & Vines (Y & Pomace & 912 & 717 & 391 & $\mathrm{~L}$ \\
\hline & Vines (X19) & Firewood & 2,442 & & & $\mathrm{DU}+\mathrm{F}$ \\
\hline & & Leaves & 1,250 & & & $\mathrm{~F}$ \\
\hline$\bigotimes_{\mathscr{D}}$ & Fallow $\left(X_{20}\right)$ & Pasture & 1,523 & & & $\mathrm{~L}$ \\
\hline 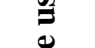 & Pasture $\left(\mathrm{X}_{21}\right)$ & Pasture & 3,947 & & & $\mathrm{~L}$ \\
\hline$\cdot \frac{7}{2}$ & & Firewood & 5,438 & 4,078 & 2,719 & $\mathrm{DU}+\mathrm{F}$ \\
\hline 巳一 & Forest $\left(\mathrm{X}_{22}\right)$ & Pasture & 1,523 & & & $\mathrm{~L}$ \\
\hline$\stackrel{x}{x}$ & & Oak acorns & 187 & & & $\mathrm{~L}$ \\
\hline
\end{tabular}

Sources: the same listed in Table 1 and given in the text.

\footnotetext{
${ }^{2}$ Potatoes were grown in first quality soil, both in the rotation of herbaceous dry land (1,679 kg/ha) and olive dry land $(1,250 \mathrm{~kg} / \mathrm{ha})$
} 


\subsection{Objective functions}

After setting the whole range of constraints to define the biophysical and technical limits of the agroecosystem considered, the last step before running the model was to define objective functions. We optimized the resulting model according to the goals farmers might have adopted under the prevailing conditions. Therefore, we considered three functions that characterize different farming goals: $i$ ) land-saving: the minimum surface area required to ensure reproducible exploitation, called the Minimum Reproduction Unit (MRU; Eq. 1); ii) labour-saving: the area required for funds' reproduction while minimizing total labour, or the Peasant Reproduction Unit (PRU; Eq. 2); and iii) commercial maximization: the maximum sustainable vine-growing area or Maximum Sustainable Specialization (MSS; Eq. 3).

$$
\begin{gathered}
\min \left(\sum_{i=1}^{i=22} X_{i}\right)(\text { Eq.1) } \\
\min \left(\sum_{i=1}^{i=22} W_{i} X_{i}+f\left(X_{i}, M, Z\right)\right)(\text { Eq. } 2) \\
\max \left(X_{19}\right)(\text { Eq.3) }
\end{gathered}
$$

where $X_{i}$ is the area of each land use, $W_{i}$ the number of workdays required for each land use, $f\left(X_{i}, M, Z\right)$ is the number of workdays associated with fertilization practices resulting from the model, and $X_{19}$ is the vineyard area.

Each farming goal will result in a different type of scenario (whether MRU, PRU or MSS). However, relying on the literature and because of the actual relevance of historical vineyard specialization in the study area, we considered three different sub-scenarios for MSS. While MSS1 will be restricted by all the specific constraints of section 4.4, MSS2 will consider the ability to import labour from outside the farm/municipality (thus constraints regarding to human labour will not be applied), as was actually happening in the area (Garrabou et al., 2015). Finally, together with considering that labour was not to be satisfied locally, MSS3 will consider the ability to import a share of the diet from outside the system boundaries, as historical sources support around $26 \%$ of staple grains was locally imported, mainly in the form of wheat coming from inner Spain (Garrabou, Cussó \& Tello, 2007: 201). All these scenarios will be modelled assuming equal access to land. This methodological assumption is key to then compare the simulated results with the actual ones in a way 
that reveals the role played by inequality to shift the real configuration away from those optimal scenarios.

\section{Results}

\subsection{The metabolism of a Minimum Reproduction Unit}

The first objective function minimizes the land requirements of the farming population (Eq. 1) to assess the existing capacity for sustainable land-use intensification by identifying the minimum land cost to maintain the three funds. This strategy seeks to accommodate as much of the population as possible on the available land. The results are shown in Figure 3. In order to meet the food, fuel and income requirements of the domestic unit, the surface area needed would have been 3.77 ha (case 1). Notice that, in this case, the DU would have had to buy meat and fertilizers, as there would not have been domestic animals neither soil nutrient replenishment.

Figure 3. Scenario of MRU by goals, for a family of five people. ${ }^{3}$ Source: Our own.

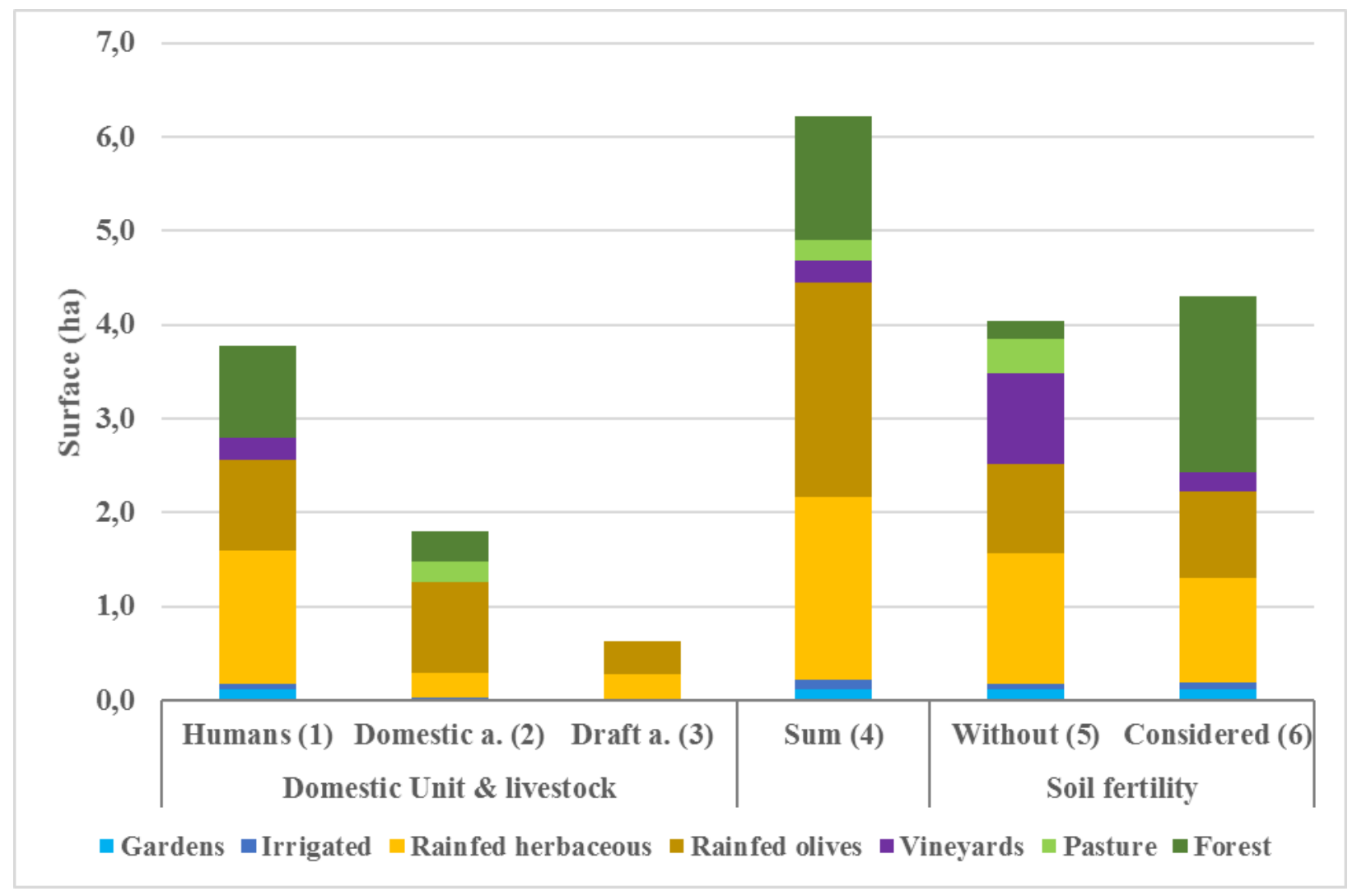

\footnotetext{
${ }^{3}$ As you can see in this figure, we present the three funds as separate goals. While in the case of DU and animals (separated by draft power and other domestic animals) we can analyse them separately, fertilization has intrinsically not a cost on surface; you can calculate the increase of the total land cost due to fertilization only with respect to other requirements.
} 
For livestock reproduction, which would have included two sheep, a pig and some chickens and rabbits as assumed in the estimated historical average of a domestic unit, an additional 1.81 ha would have been required (case 2). The high proportion of the previously calculated area that this entails reflects the required rotation with dryland olive groves, and is consistent with the need to produce fodder legumes (e.g. lupins) to feed the livestock (Roca, 2007). Feeding the share of annual feed that corresponds to the 0.25 mule required for ploughing would have entailed an additional 0.63 ha (case 3). Therefore, to guarantee the reproduction of both the DU and livestock funds, and if we make the sum of these three surface areas cumulative (i.e., if each one was devoted to fulfilling a single goal), our standard DU would have required a total of 6.21 ha of farmland (case 4).

However, by taking advantage of the existing multipurpose character of peasant land and livestock uses (e.g. farmers used forest for pasture and for firewood and timber provision), together with the possibility of using crop by-products for animal feeding, the minimum area actually required for such a family farm would have been reduced from 6.21 to 4.04 ha (case 5). This demonstrates the existence of land-use synergies among funds.

Feeding livestock in ways that did not compete with human food also played an important role on the total surface area required. While in the first run of the model (cases $2 \& 3$ ) animals would have been fed with main crop products, such as corn or vegetables, in the second run (case 5) animal intake would have relied on crop by-products such as straw or pomaces and on natural pastures (Table 3).

Other fund-flow synergies between different compartments of the agroecosystem appeared when soil fertility maintenance was taken into account. As a result, land-use synergies and livestock multifunctionality reduced the total area required to reproduce the farm unit by $54 \%$. At first glance the maintenance of nutrient cycles in cultivated soils did not significantly affect the total useful area needed: surface only increased by 7\%, from 4.04 to 4.31 ha (case 6; Table 3). However, this increase of 0.27 ha would also have been associated with a change in the use of pastures in favour of forest as a nutrient supplier, as well as the restructuring of land uses according to soil quality. 
Table 3. Main results of the scenarios by fund. Source: Our own.

\begin{tabular}{|c|c|c|c|c|c|c|c|}
\hline & & Units & MRU & RPU & MSS(1) & MSS(2) & MSS(3) \\
\hline \multirow{11}{*}{$\underset{\substack{\mathbb{E} \\
\text { 壳 }}}{\mathbb{E}}$} & Vegetable gardens & \multirow{8}{*}{ На } & $0.12(3 \%)$ & $0.12(2 \%)$ & $0.12(1 \%)$ & $0.12(1 \%)$ & $0.12(1 \%)$ \\
\hline & Irrigated & & $0.07(2 \%)$ & $0.09(2 \%)$ & $0.00(0 \%)$ & $0.13(2 \%)$ & $0.13(2 \%)$ \\
\hline & Herbaceous crops & & $1.12(26 \%)$ & $1.55(26 \%)$ & $1.86(23 \%)$ & $0.99(12 \%)$ & $0.51(6 \%)$ \\
\hline & Olive groves & & 0.93 (22 \%) & $0.23(4 \%)$ & $0.35(4 \%)$ & $0.29(3 \%)$ & $0.26(3 \%)$ \\
\hline & Vineyards & & 0.19 (5 \%) & $0.81(14 \%)$ & $2.12(26 \%)$ & $4.77(58 \%)$ & $5.43(66 \%)$ \\
\hline & Pastures & & $0.00(0 \%)$ & $0.94(16 \%)$ & $1.29(16 \%)$ & $0.87(11 \%)$ & $1.30(16 \%)$ \\
\hline & Forest & & 1.88 (44 \%) & 2.09 (36 \%) & $2.51(30 \%)$ & $1.09(13 \%)$ & $0.50(6 \%)$ \\
\hline & Total surface & & 4.31 & 5.83 & 8.25 & 8.25 & 8.25 \\
\hline & Humanure & \multirow{3}{*}{$\operatorname{kg} \mathrm{N}$} & $22.10(32 \%)$ & 22.10 (32 \%) & 22.10 (22 \%) & $22.10(19 \%)$ & $22.10(19 \%)$ \\
\hline & Manure & & $22.24(32 \%)$ & 21.98 (32 \%) & 23.79 (23 \%) & $27.71(24 \%)$ & $27.03(23 \%)$ \\
\hline & Burying biomass & & 25.77 (36 \%) & 24.98 (36 \%) & 56.27 (55 \%) & $66.46(57 \%)$ & 68.55 (58 \%) \\
\hline \multirow{4}{*}{ 。 } & Labour & \multirow{3}{*}{ workdays } & $434(68 \%)$ & 367 (57 \%) & 467 (72 \%) & 555 (86 \%) & $564(85 \%)$ \\
\hline & Labour April & & $29(55 \%)$ & $24(46 \%)$ & 47 (99 \%) & $76(144 \%)$ & 84 (159 \%) \\
\hline & Labour October & & $17(38 \%)$ & $21(49 \%)$ & 35 (100\%) & $67(154 \%)$ & 73 (168 \%) \\
\hline & Gross revenues & Pesetas & 984 & 979 & 1,045 & 1,419 & 1,434 \\
\hline \multirow{3}{*}{ 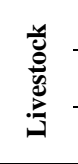 } & Pasture & \multirow{3}{*}{$\mathrm{kg} \mathrm{ms}$} & 1,604 (37 \%) & $13,585(73 \%)$ & $17,452(73 \%)$ & $15,124(56 \%)$ & $16,061(58 \%)$ \\
\hline & By-products & & 2,714 (63 \%) & $2.587(16 \%)$ & 4,906 (22 \%) & $10,333(41 \%)$ & $8,541(35 \%)$ \\
\hline & Grains and forages & & $0(0 \%)$ & 2.436 (13 \%) & 1,595 (7 \%) & $1,767(6 \%)$ & 2,921 (11\%) \\
\hline \multirow{2}{*}{ 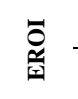 } & FEROI & \multirow{2}{*}{ Adim. } & 0.43 & 0.49 & 0.31 & 0.24 & 0.23 \\
\hline & FEROL & & 33.80 & 50.97 & 39.31 & 24.84 & 24.09 \\
\hline
\end{tabular}

Source: Our own, from the sources given in the text and previous tables. EROI: Energy Return on Inputs; FEROI: Final EROI; FEROL: Final Energy Return on Labour; see Tello et al. (2016). Adim means adimensional values.

\subsection{An extensification scenario based on the minimum labour needed for a Peasant Reproduction}

\section{Unit (PRU)}

The land surface area required to minimize the labour applied under a PRU scenario would have been 5.83 ha for a five-person family in Sentmenat c. 1860, 29\% higher than for a land-saving MRU strategy (see Figure 4 and Table 3). In addition, this labour-saving strategy would entail changes in land use patterns. As expected, more extensive use increased the surface under pasture and forest by over 52\%. Vineyards increased by $14 \%$. The latter illustrates their role as a cash crop, in contrast with the MRU scenario, in which olive groves played a major role. Cereal rotation associated with olive trees yielded higher gross revenues than vineyards, but required $87 \%$ more labour per hectare. Therefore, the aim of minimizing labour costs and achieving higher net incomes favoured the growth of vines instead of olive trees. 


\subsection{The Maximum Sustainable Specialization (MSS) scenario to expand the vine-growing strategy}

By means of the third scenario, we calculated what the highest share of vineyard would have been under equal access to land while ensuring the reproduction of funds, and identifying the factors limiting the further expansion of vines. This allows us to go deeper into the analysis of the role specialization in vine growing played in our case study. Figure 4 shows the results obtained using additional assumptions. The average farm size for five people would have been 8.25 ha/DU. If we consider the need to satisfy the required reproduction flows of the three funds (MSS1), the highest share of land devoted to vines would have been $26 \%$, far below the $42 \%$ recorded in c. 1860 . In this case labour availability appears to have been the limiting factor to vineyard specialization, especially during the key months of October (harvest) and April (leaf removal) (Table 3). If we then consider the feasibility of hiring external labour in these peak seasons, as was the case in Catalonia at that time (Garrabou et al., 2015), vineyard specialization would increase to 58\% of the cropland area (MSS(2)). If we wonder why vine growing did not reach this level in 1860, we immediately see that it would have been necessary to clear more forestland, brushwood and pastureland. About $22 \%$ of the total surface was forest and pasture at that time, and cultivating an additional 416 hectares would have involved a huge amount of labour, and an important opportunity cost in terms of firewood, timber, wood pasture and nutrients for cropland. Here, too, comes the role of inequality: wealthy landowners preferred to save labour and wage costs, while maintaining their own supply of firewood and pasture, to avoid too risky market dependence (Garrabou, Cussó \& Tello, 2007; Pascual, 1990; Bhaduri, 1986).

Finally, in model MSS3, crops would only meet the fraction of the local diet consisting of vegetables and fruits. Vineyards could have been grown on $66 \%$ of the whole municipal area (MSS3), but the village would have had to import $44 \%$ of its diet, mainly in the form of wheat and potatoes. 
Figure 4. MRU and RPU scenarios, MSS according to the limiting factors considered and actual landuse distribution by deciles of surface (for 191 farms) and average value c.1860 in Sentmenat. Source: Our own.

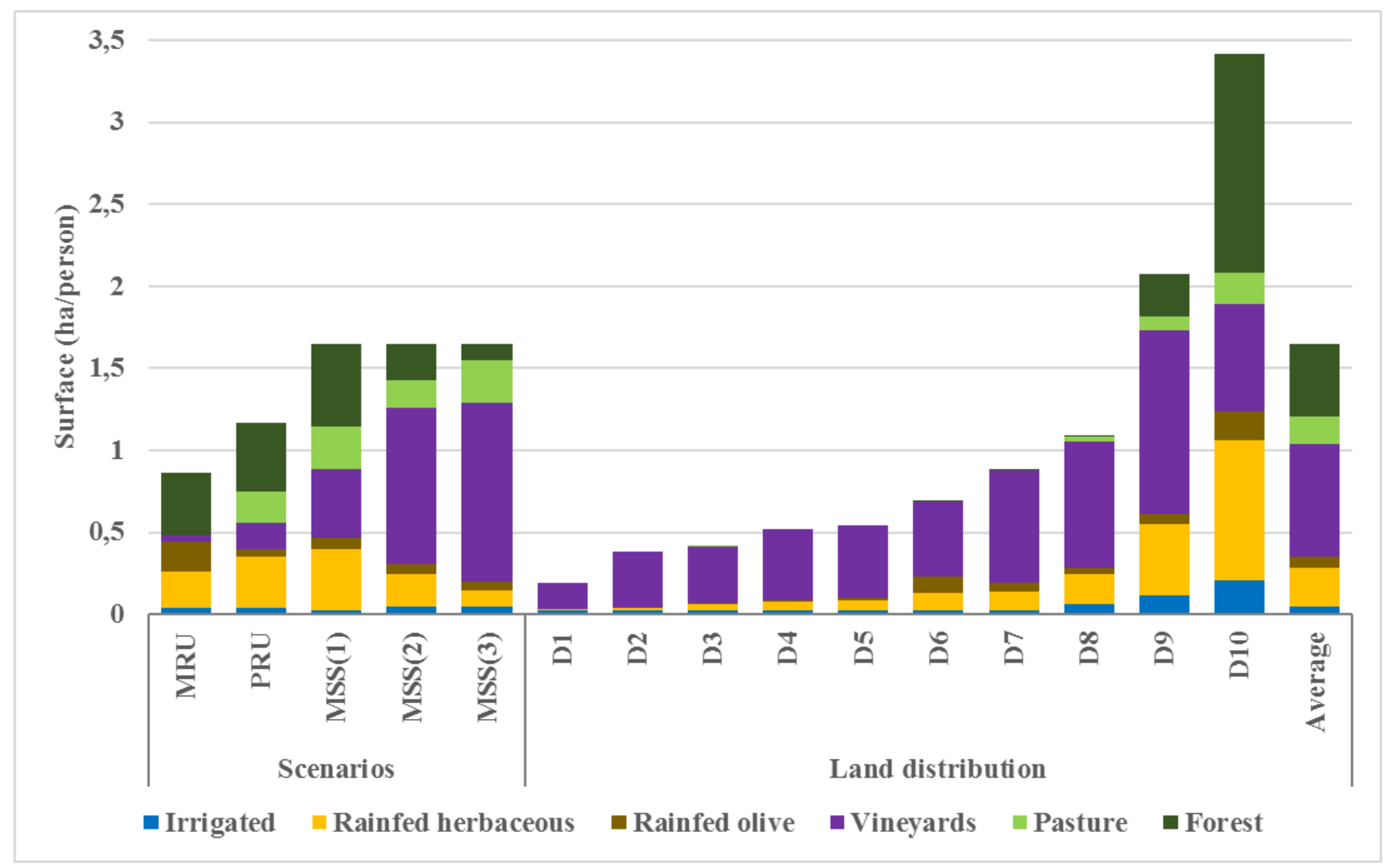

\section{Discussion}

\subsection{Landscape synergies and trade offs}

As it has long been stressed in the study of carrying capacities, defining biophysical limits for the anthropogenic use of ecosystems has to explicitly consider which goal is going to be optimized (Murray, 2009). This is something that our optimization model can assess with the different kinds of goals, in order to determine the diverse area requirements and land use patterns required. The comparison between our counterfactual SAFRA scenarios and the actual situation makes the reliability of linear optimization models apparent. They offer a means of socio-metabolic accountancy that is able to reveal the different configurations that agroecosystems and land uses could have had, all sustainable, depending on the main goals farmers might have adopted.

The Minimum Reproduction Unit (MRU) revealed that the cost maintaining the three funds altogether, was only 0.54 ha above the 3.77 ha required to maintain the DU alone, i.e. an additional $14 \%$ of surface (figure 3). Therefore, here comes the meaning of our first main result: despite there is a 
Land Cost of Agrarian Sustainability (i.e. the amount of land required by agricultural activity to maintain its ecological functioning or LACAS; Guzmán and González de Molina, 2009), thanks to the synergic interlinkages that can set among funds, the total reproduction costs are not necessarily a cumulative sum (Lemaire and Franzluebbers, 2014; Marull and Tello, 2010).

The generation of internal loops through biomass reuse is highly relevant when we search for the reasons behind this fund-flow synergism that resulted in a significant saving of land. As the amount of available manure was not enough for soil nutrients replenishment, farmers had to rely on burying biomass to keep the reproduction of the soil fund. To cover $36 \%$ of the total nitrogen replenishment in this way would entail a highly labour-intensive task. This explains why the maintenance of soil fertility produced a decrease in the overall energy efficiency (FEROI, the amount of energy product per total input), which dropped from 1.18 to 0.43 . Likewise, labour energy efficiency (FEROL) decreased from 59.0 to 33.8 MJ produced per MJ of labour performed.

Therefore, we conclude that more intensive land use required a greater flow of biomass reuse (BR), which in turn led to a decrease in energy efficiency. So, land-use intensity also determines what the energy returns may be. This means that taking as a single criterion the final energy efficiency (FEROI), regardless of the reproduction of funds and the LACAS involved in relation to the degree of intensification, would result in what Georgescu-Roegen (1971) criticized as an 'energetic dogma'. Hence, the high BR and labour costs of land-use intensification have to be taken into account when assessing the energy efficiency of organic agricultural systems.

The MRU land-intensive results, which gave an average of 0.86 ha of surface area required per person, are the most comparable to other previous Chayanovian reproductive studies performed in Catalonia for the same period. This value is consistent with a rough estimate made only in monetary terms by Garrabou and Tello (2008), according to which 4-5 ha of wheat were necessary to maintain an average family of 4.5 people in the same period and study area. Other studies in other Catalan regions estimated a range from 3 to 5 ha in similar soil, climate and technical conditions (Vicedo et al., 2002; Garrabou et al. 2014). Thus, land distributions of less than 0.86 ha/person would not have allowed internal reproduction of peasant farms, and families would have been compelled either to 
perform off-farm work to earn money, or to sell their own farm products to pay for the external goods acquired in the markets to fulfil self-reproduction. Indeed, they might also have transferred part of this pressure towards other funds (e.g. through soil nutrient mining), thus hindering the conditions required for sustainable reproduction.

As Chayanov argued, a peasant economy might respond to different criteria other than labour allocation efficiency, crop diversification and risk minimization (Chayanov, [1925]1986). Peasants might also have been interested in minimizing labour, provided that their land endowment would allow this. This is what the Peasant Reproduction Unit (PRU) scenario considers. When comparing the landintensive MRU scenario with the labour-saving PRU scenario, we found that, in order to achieve the reproduction goals of a peasant family with a lower labour requirement, a PRU strategy required a land surface at its disposal 35\% larger. Conversely, energy labour productivity (FEROL) would have increased by 51\%, from 33.8 to 51.0 MJ per MJ. These results highlight the existence of a crucial trade-off between labour intensity and land cost (Sahlins, 1971; Gingrich et al., 2018). However, in the PRU case gains in labour productivity would have been higher than land costs. Therefore, the laboursaving PRU strategy would have meant an improvement in population wellbeing in terms of consumption-labour ratios, with only a moderate increase in land available for each peasant unit.

\subsection{How land use distribution satisfied different farm goals}

SAFRA modelling scenarios, and their biophysical fund-flow patterns, allow a better understanding of how different societal goals would have led to different land-use configurations. However, in order to check to what extent these results resembled to reality, we compare them with the actual distribution of land. Beyond its usefulness for environmental history analysis, this is also relevant to verify the reliability for the model to perform prognoses at present, and obtain information regarding the agroecological intensification processes currently proposed (FAO, 2013).

We made use of a database constructed by matching the census of 1855 and the land register of 1850, which contains information for 191 domestic units that represented $89 \%$ of the agrarian population and $65 \%$ of the total surface area of Sentmenat municipality (Marco et al., forthcoming). We sorted them 
by the average surface/person, and grouped the resulting distribution by deciles (from D1 to D10; figure 4). Then we compared how the actual farm land-use distribution of the 191 domestic units resembled the modelling scenarios by calculating the cumulative sum of the absolute differences between the percentages of each land use (the Euclidean distances). We considered those real farms whose land-use patterns scored more than $30 \%$ of the Euclidian distance to the SAFRA-modelled patterns as bearing no resemblance to these alternative scenarios. This allows us to shed light on some of the reproduction conditions required to maintain their own DU, livestock and soil fertility, as well as on the likely farming goals they might have mainly pursued.

Table 4. Resemblance (Euclidean distance $<30 \%$ ) of actual farms with the counterfactual scenarios considered, distributed in deciles by the average surface per person available in each domestic unit. Source: our own.

\begin{tabular}{|c|c|c|c|c|c|c|c|c|}
\hline Decile & MRU & PRU & MSS(1) & MSS(2) & MSS(3) & NONE & Total & $\begin{array}{c}\text { Average } \\
\text { surface } \\
\text { person }\end{array}$ \\
\hline D1 & & & & 5 & 12 & 2 & 19 & 0,17 \\
\hline D2 & & & & 4 & 15 & & 19 & 0,36 \\
\hline D3 & & & & 3 & 14 & 2 & 19 & 0,40 \\
\hline D4 & & & & 5 & 13 & 1 & 19 & 0,50 \\
\hline D5 & & & & 5 & 12 & 2 & 19 & 0,52 \\
\hline D6 & & & & 6 & 10 & 4 & 20 & 0,67 \\
\hline D7 & & & & 3 & 12 & 4 & 19 & 0,85 \\
\hline D8 & & & & 5 & 11 & 3 & 19 & 1,06 \\
\hline D9 & & 1 & 4 & 6 & 5 & 3 & 19 & 2,05 \\
\hline D10 & 2 & 7 & 8 & 1 & & 1 & 19 & 3,39 \\
\hline Total & 2 & 8 & 12 & 43 & 104 & 22 & 191 & $1,32 *$ \\
\hline
\end{tabular}

We found that $89 \%$ of farms fit with the land-use pattern of the scenarios considered to date (assuming Euclidian distances lower than 30\%; Table 4). It is clear from these results that the actual land distribution did not respond to the basic needs of peasants’ self-sufficiency through land-saving (MRU), as only two farms in the whole municipality fit more with MRU than any other scenario. More than $60 \%$ of land distributions from deciles D1 to D8 actually resembled the specialization process of the Maximum Sustainable Specialization, specifically to MSS(3). In D9 we found that most of the farms were more similar to the commercial MSS(2) strategy, but also to the commercial MSS(3) and MSS(1), which allowed the external labour and food supplies to be increased, while for D10 the main similarity was the limited vineyard specialization MSS(1) and the labour-saving PRU. Therefore, 
among D9 and D10 76\% of farms were approaching an autonomous reproductive strategy through either vineyard specialization MSS(1) and MSS(2), or by following the labour-saving PRU strategy (only two of them fitted the land-saving MRU case), which is consistent with the fact that they had enough land to do so and they opted for less intensive land uses in order to spare labour hired and reduce their dependence on markets for firewood provision and animal feeding (Marco et al., forthcoming; Garrabou, Cussó \& Tello, 2007).

In farms up to the D8 percentile, there was not enough land per person to follow autonomous reproductive strategies at the farm level without heavily relying on the labour and goods markets—a well-known feature sometimes called ‘forced commerce’ (Bhaduri, 1986; Tello, 1990). We calculate that, in order to earn enough money to buy all the goods required to survive (food and wood, housing and clothes), and to pay taxes, around 0.56-0.63 ha/person would have been required. This level was not reached until D6, meaning that at least $60 \%$ of farms would have been forced to sell labour to earn enough money for survival. Previous work using other approaches showed a slightly higher percentage at around 73\% (Marco et al., forthcoming).

Various agroecological problems were identified in our analysis. In Tello et al. (2012) and Galán del Castillo (2012) the nutrient analysis done at the same municipal level showed a lack of nitrogen replenishment in mid-nineteenth century. When analysing the flow of soil nutrients at the farm level we noticed that these local problems could be concentrated in particular social strata. As seen in Table 3, in all the commercial MSS scenarios burying biomass was the most important strategy to close nutrient cycles. An important share of this biomass came from forests as green shoots and litter. However, below D9 the share in the forest was insufficient to ensure this type of nutrient replenishment, which probably meant that many of these farms were mining soil nutrients. Those smallholders without sufficient access to woodland had to rely on their own vine pruning, and faced the dilemma of either using them for heating and cooking at home or fertilizing their vineyards. This in turn was validated by sources regarding prosecutions due to plundering in the large landowners' forests (Roca, 1997), and helps explain the use of highly labour-intensive practices in vineyards such 
as burning the so-called 'formiguers' due to the scarcity of other fertilizing sources (Garrabou and Planas, 1998; Olarieta et al., 2011).

Finally, by comparing D9 and D10 with the limited commercial MSS(1) and the land-saving MRU strategy it becomes apparent that such farms had a surplus in terms of food, mainly cereals, which means that local food security with respect to basic grains was mainly in the hands of the richest landowners.

\section{Conclusions}

In this paper we lay the foundations of a Sustainable Agroecological Farm Reproductive Analysis (SAFRA) through socio-metabolic optimization modelling of the different flows that interlinked three live funds for agroecosystem sustainability in a historical case study: the peasant family unit, the livestock, and farmland. Our SAFRA model relies on the approaches put forward by Alexander V. Chayanov ([1925]1985; Van der Ploeg, 2014) and food systems analysis, and goes beyond them by adopting a socio-metabolic perspective from a fund-flow analytical standpoint. It can be used for counterfactual historical analysis, as in the example provided here, although it is mainly aimed at generating scenarios for more sustainable farm systems based on the biophysical limits and capacities of agroecosystem functioning at present.

Regarding the limitations of the model, in this initial version we only assessed three main funds of the agroecosystem, putting aside the farmland-associated biodiversity that we intend to assess in further research by including the links between social metabolism and landscape ecology (Marull et al., 2018). We consider this a first step towards linking Social Metabolism with Environmental History through quantitative counterfactual analysis. The degree of resemblance of the SAFRA-modelled counterfactuals obtained in the initial test of this article with the actual land distributions in the example used hints at the robustness of the model. However, the model only considers static yields, and could lead to underestimates in years with extreme weather or crop failures. Moreover, the main forthcoming challenge will lie in using improved versions to develop prospective scenarios to help 
deliberative processes on how agroecological funds could be managed to achieve sustainable agroecosystems in the future.

For the first time, the results of this study have quantitatively assessed the synergies that can take place among land uses and land-livestock relationships to reduce land requirements when funds are closely integrated. Agroecosystem funds have a dual role, as suppliers and consumers of biophysical flows. By linking the product and by-product flows of one fund to another, the amount of land required to meet their reproductive needs could be substantially reduced. This is relevant when assessing the Land Cost of Sustainability or LACAS (Guzmán and González de Molina, 2009), and the Energy Returns on Inputs of agroecosystems (Tello et al., 2016; Galán et al. 2016). This raises concerns regarding the competition among land uses devoted to feeding animals or to providing food for humans (Haberl, 2015). We consider that our SAFRA model could help to better understand the key drivers at stake, and to plan more sustainable farm systems.

As an applied history research, the results show how by integrating the management of farmland and livestock, which nowadays would be associated with eco-functional intensification practices (FAO, 2013), was a relevant strategy to achieve sustainable farm systems in the context of increasing population densities under past organic conditions despite the greater effort in terms of human labour they required. This is also relevant for advancing organic farming towards more agroecological landscapes and territories (Wezel et al. 2016). These findings highlight the relevant role that forests and pastures can play as soil nutrient suppliers, when they are agroecologically integrated with cropland through a complex multipurpose livestock feeding strategy (Krausmann, 2004). They show the importance of retaining complex crop rotations and multi-crop associations, as farmers did in past organic agricultural systems, which created agroecologically functional landscape mosaics (Cattaneo et al., 2019; Marull et al., 2008; Tello and González de Molina, 2017). They also make apparent the greater labour efficiency obtained by following an extensive strategy instead of only promoting a higher rural population density when searching for more equitable land distributions. Last but not least, they show that a certain degree of cash-crop specialization can be implemented while maintaining relevant levels of local food sovereignty in a sustainable manner, but only as long as some key 
biophysical cycles can be closed within a functional agroecological territory (Wezel et al., 2016; Marull et al., 2016; Tello and González de Molina, 2017).

\section{Acknowledgements}

This work has been supported by the Spanish research project HAR2015-69620-C2-1-P, and the international Partnership Grant SSHRC-895-2011-1020 on 'Sustainable farm systems: long-term socio-ecological metabolism in western agriculture' funded by the Social Sciences and Humanities Research Council of Canada. The corresponding author was also granted with two scholarships from the Spanish Ministery of Economy and Competitiveness with references BES-2013-06415 and EEBBI-17-12073.

\section{References}

Altieri, M.A, Nicholls, C.I. 2012. Agroecology Scaling Up for Food Sovereignty and Resiliency. In: Lichtfouse E. (eds.) Sustainable Agriculture Reviews. Sustainable Agriculture Reviews. Dordrecht: Springer, pp. 1-29. https://doi.org/10.1007/978-94-007-5449-2_1

American Society of Agricultural Engineers (ASAE), 2000. Manure production and characteristics. Saint Joseph.

Antrop, M., 2005. Why landscapes of the past are important for the future. Landsc. Urban Plan. 70, 21-34. doi:10.1016/j.landurbplan.2003.10.002

Bhaduri, A., 1986. Forced commerce and agrarian growth. World Development 14(2):267-272; https://doi.org/10.1016/0305-750X(86)90058-6)

Badia-Miró, M., Tello, E., 2014. Vine-growing in Catalonia: The main agricultural change underlying the earliest industrialization in Mediterranean Europe (1720-1939). Eur. Rev. Econ. Hist. 18, 203-226. doi:10.1093/ereh/heu006

Badia-Miró, M., Tello, E., Valls, F., Garrabou, R., 2010. The grape Phylloxera plague as a natural experiment: The upkeep of vineyards in Catalonia (Spain), 1858-1935. Aust. Econ. Hist. Rev. 50, 39-61. doi:10.1111/j.1467-8446.2009.00271.x

Bayliss-Smith, T.P., 1982. The ecology of agricultural systems. Cambridge University Press, Cambridge.

Bettoni, L., 2009. Gusek.

Bhaduri, A., 1998. Eficiencia económica e instituciones agrarias. Hist. Agrar. 15, 15-25.

Cardinale, B.J., Duffy, J.E., Gonzalez, A., Hooper, D.U., Perrings, C., Venail, P., Narwani, A., MacE, 
G.M., Tilman, D., Wardle, D.A., Kinzig, A.P., Daily, G.C., Loreau, M., Grace, J.B., Larigauderie, A., Srivastava, D.S., Naeem, S., 2012. Biodiversity loss and its impact on humanity. Nature 486, 59-67. doi:10.1038/nature11148

Cartwright, N., 2007. Counterfactuals in Economics: A commentary, in: Hunting Causes and Using Them: Approaches in Philosophy and Economics. MIT Press, Cambridge, pp. 191-216.

Cascón, J., 1918. Problemas agrícolas. El estiércol y la alimentación animal. Imprenta de Alrededor del Mundo, Madrid.

Cattaneo, C., Marull, J., Tello, E., Cattaneo, C., Marull, J., \& Tello, E., 2018. Landscape Agroecology. The Dysfunctionalities of Industrial Agriculture and the Loss of the Circular Bioeconomy in the Barcelona Region, 1956-2009. Sustainability, 10(12), 4722. https://doi.org/10.3390/SU10124722 Chayanov, A. V, 1925. La organización de la unidad económica campesina. Ediciones Nueva Visión, Buenos Aires.

Church, D.C., 1984. Alimentos y alimentacion del ganado. Tomo II. Hemisferio sur, Buenos Aires. Colomé, J., 2015. Pequeña explotación agrícola, reproducción de las unidades familiares campesinas y mercado de trabajo en la viticultura mediterránea del siglo XIX: el caso catalán. Rev. Hist. Económica 18, 281-307. doi:10.1017/CBO9781107415324.004

Colomé, J., 1996. L’especialització vitícola a la Catalunya del segle XIX. Universitat de Barcelona. Congost, R., Ferrer, L., \& Saguer, E., 2015. The transformations of the Mas system and of late modern agricultural landscape (since 1800). In R. Congost (Ed.), The catalan Mas: Origins, transformations and the end of an agrarian system. Girona: Biblioteca d'Historia Rural.

Cronon, W., 1991. Nature’s metropolis. Norton, New York.

Cussó, X., Garrabou, R., 2012. Alimentació i nutrició al Vallès Occidental. Un segle i mig de canvis i permanències: 1787-1936 (No. 2012_05), Unitat d'Història Econòmica. Barcelona.

Cussó, X., Garrabou, R., Olarieta, J.R., Tello, E., 2006. Balances energéticos y usos del suelo en la agricultura catalana: una comparación entre mediados del siglo XIX y finales del siglo XX. Hist. Agrar. 471-500.

Dantzing, G.B., 1963. Linear Programming and Extensions. Princeton University Press, Princeton. Desjardins, E., MacRae, R., Schumilas, T., 2010. Linking future population food requirements for health with local production in Waterloo Region, Canada. Agric. Human Values 27, 129-140. doi:10.1007/s10460-009-9204-y

Food and Agriculture Organization of the United Nations (FAO), 2013. Comparative table : Ecofunctional , sustainable and ecological intensification. Rome.

Fischer-Kowalski, M., Haberl, H., 2007. Socioecological Transitions and Global Change. Trajectories of Social Metabolism and Land Use. Edward Elgar, Cheltenham.

Fogel, R., 1964. Railroads and American Economic Growth. Johns Hopkins Press, Baltimore. Fundacion Española para el Desarrollo de la Nutrición Animal (FEDNA), 2010. Tablas FEDNA de 
composicion y valor nutritivo de alimentos para la fabricacion de piensos compuestos (3a edicion). Madrid.

Gabrel, V., Mural, C., Thiele, A., 2014. Recent Advances in Robust Optimization and Robustness : An Overview Theory of Robust Optimization and Robustness. Eur. J. Oper. Res. 235, 471-483. doi:10.1016/j.ejor.2013.09.036

Galán, E., 2017. Feeding soils: nutrient balance in the northeast of the Iberian Peninsula c. 1920. Historia Agraria 72: 107-134.

Galán, E., Padró, R., Marco, I., Tello, E., Cunfer, G., Guzmán, G.I., González de Molina, M., Krausmann, F., Gingrich, S., Sacristán, V., Moreno-Delgado, D., 2016. Widening the analysis of Energy Return on Investment (EROI) in agro-ecosystems: Socio-ecological transitions to industrialized farm systems (the Vallès County, Catalonia, c.1860 and 1999). Ecol. Modell. 336, 13-25. doi:10.1016/j.ecolmodel.2016.05.012

Galán, E., Tello, E., Cussó, X., Olarieta, J.R., 2012. Métodos de fertilización y balance de nutrientes en la agricultura orgánica tradicional de la biorregion mediterránea: Cataluña (España) en la década de 1860. Hist. Agrar. 95-119.

Garrabou, R., Planas, J., 1998. Estudio Agrícola del Vallès 1874. Impremta de Granollers, Granollers. Garrabou, R., Pujol, J., Colomé, J., Saguer, E., 1992. Estabilidad y cambio de la explotación campesina (Cataluña, siglo XIX-XX). Prop. y Explot. campesina en la España Contemp. 15-92.

Garrabou, R., Cussó, X. \& Tello, E., 2007. La persistència del conreu de cereals a la provincia de Barcelona a mitjan segle XIX. Estudis d’Història Agrària 20:163-219.

Garrabou, R., Planas, J.; Saguer, E. and Vicedo, E., 2014. Propiedad de la tierra y desigualdad social en el mundo rural catalán de mediados del siglo XIX. Historia Agraria 63: 115-150.

Garrabou, R., Ramon-Muñoz, J.-M., Tello, E., 2015. Organització social del treball, salaris i mercat laboral a Catalunya: el cas d’una explotació agrària de la comarca de Segarra a la darreria del segle XIX. Recerques. Història, Econ. Cult. 70, 88-123.

Garrabou, R., Tello, E., 2008. L’especialització vitícola catalana i la formació del mercat blader espanyol : una nova interpretació a partir del cas de la província de Barcelona. Recerques 57, 91134.

Garrabou, R., Tello, E., Cussó, X., 2010. Ecological and Socioeconimc functioning of the Valles county in 1850-1870, in: Landsteiner, E., Langthaler, E. (Eds.), Agrosystems and Labour Relations in European Rural Societies. Turnhout Brepols Publishers, pp. 119-154.

Garrabou, R., Tello, E., Cussó, X., 2008. El cambio en los usos del suelo en la comarca catalana del Vallès (1850-2000): fuerzas motoras y agentes rectores en la transformación del territorio, in: El Paisaje En Perspectiva Histórica. Formación Y Transformación Del Paisaje En El Mundo Mediterráneo. Prensas universitarias de Zaragoza, Zaragoza, pp. 233-258.

Georgescu-Roegen, N., 1971. The Entropy Law and the Economic Process. Harvard University Press, 
Cambridge.

Gerber, J.F., Scheidel, A., 2018. In search of substantive economics : comparing today's two major socio-metabolic approaches to the economy - MEFA and MuSIASEM. Ecol. Econ. 144, 186194.

Gerber, J.D., Gerber, J.F., 2017. Decommodification as a foundation for ecological economics. Ecol. Econ. 131, 551-556. doi:10.1016/j.ecolecon.2016.08.030

Giampietro, M., 1997. Socioeconomic constraints to farming with biodiversity. Agric. Ecosyst. Environ. 63, 145-167. doi:10.1016/S0167-8809(97)00014-5

Giampietro, M., Mayumi, K., Sorman, A.H., 2013. Energy Analysis for Sustainable Future: MultiScale Integrated Analysis of Societal and Ecosystem Metabolism. Routledge, London.

Gingrich, S., Marco, I., Aguilera, E., Padró, R., Cattaneo, C., Cunfer, G., Guzmán, G.I., MacFadyen, J., Watson, A., 2018. Agroecosystem energy transitions in the old and new worlds : trajectories and determinants at the regional scale. Regional Environmental Change, 18, 1089-1101. https://doi.org/10.1007/s10113-017-1261-y

Gizicki-Neundlinger, M., Gingrich, S., Güldner, D., Krausmann, F., Tello, E., 2017. Land, Food and Labour in Pre-Industrial Agro-Ecosystems. A Socio-Ecological Perspective on Early 19th Century Seigneurial Systems. Hist. Agrar. 1-47.

Gizicki-Neundlinger, M., Güldner, D., 2017. Surplus, Scarcity and Soil Fertility in Pre-Industrial Austrian Agriculture-The Sustainability Costs of Inequality. Sustainability 9, 265. doi:10.3390/su9020265

Gliessmann, S., 1998. Agroecology: ecological processes in sustainable agriculture. Lewis Publishers, London.

González de Molina, M., García Ruiz, R., Guzmán, G.I., Soto, D., Infante, J., 2010. Guideline for constructing nutrient balance in historical agricultural systems (and its application to three casestudies in southern Spain) (No. 1008), DT-SEHA. Madrid.

González de Molina, M., Guzmán, G.I., 2017. Agroecology and Ecological Intensification. A Discussion from a Metabolic Point of View. Sustainability 9, 86. doi:10.3390/su9010086 Gootas, H.B., 1956. Composting: Sanitary disposal and reclamation of organic wastes (No. 31). Grabaum, R., Meyer, B.C., 1998. Multicriteria optimization of landscapes using GIS-based functional assessments. Landsc. Urban Plan. 43, 21-34. doi:10.1016/S0169-2046(98)00099-1

Guzmán, G.I., Aguilera, E., Soto, D., Cid, A., Infante, J., García Ruiz, R., Herrera, A., Villa, I., González de Molina, M., 2014. Methodology and conversion factors to estimate the Net Primary Productivity of historical and contemporary agro-ecosystems (No. 1407), WP-SEHA.

Guzmán, G.I., González de Molina, M., 2009. Preindustrial agriculture versus organic agriculture. The land cost of sustainability. Land use policy 26, 502-510. doi:10.1016/j.landusepol.2008.07.004 Haberl, H., 2015. Competition for land: A sociometabolic perspective. Ecol. Econ. 119, 424-431. 
doi:10.1016/j.ecolecon.2014.10.002

Haberl, H., Fischer-Kowalski, M., Krausmann, F., Weisz, H., Winiwarter, V., 2004. Progress towards sustainability? What the conceptual framework of material and energy flow accounting (MEFA) can offer. Land use policy 21, 199-213. doi:10.1016/j.landusepol.2003.10.013

Harrison, M., 1975. Chayanov and the economics of the Russian Peasantry. J. Peasant Stud. 2, 389417. doi:10.1080/03066157508437947

Institut Agrícola Català de Sant Isidre (IACSI), 1879. Report number XXVIII. Amillaramientos por comarcas catalanas.

Knoke, T., Paul, C., Härtl, F., Castro, L.M., Calvas, B., Hildebrandt, P., 2015. Optimizing agricultural land-use portfolios with scarce data-A non-stochastic model. Ecol. Econ. 120, 250-259. doi:10.1016/j.ecolecon.2015.10.021

Krausmann, F., 2004. Milk, Manure, and Muscle Power. Livestock and the Transformation of Preindustrial Agriculture in Central Europe. Hum. Ecol. 32, 735-772. doi:10.1007/s10745-0046834-y

Leach, G., 1975. Energy and food production. Food Policy 1, 62-76.

Lemaire, G., Franzluebbers, A., 2014. Integrated crop-livestock systems: strategies to achieve synergy between agricultural production and environmental quality. Agric. Ecosyst. Environ. 190, 4-8. doi:10.1016/j.agee.2013.08.009

Marco, I., Padró, R., Cattaneo, C., Caravaca, J., Tello, E., 2017. From vineyards to feedlots : A fundflow scanning of sociometabolic transitions in the Vallès County (Catalonia) 1860-1956-1999. Reg. Environ. Chang. 1-13. doi:10.1007/s10113-017-1172-y

Marco, I., Padró, R., Tello, E., forthcoming. Labour, Nature and Exploitation: A first exploration on the relationships between Social Metabolism and Inequality in Traditional Organic Farm Systems. Journal of Agrarian Change.

Marull, J., Font, C., Padró, R., Tello, E., Panazzolo, A., 2016. Energy-Landscape Integrated Analysis: A proposal for measuring complexity in internal agroecosystem processes (Barcelona Metropolitan Region, 1860-2000). Ecol. Indic. 66, 30-46. doi:10.1007/s13398-014-0173-7.2 Marull, J., Pino, J., Tello, E., 2008. A landscape ecology analysis of the land-use changes in a West Mediterranean agriculture during the last 150 years: the Catalan Vallès county (1853-2004). Global Environment. A Journal of History and Natural and Social Sciences, 2, 112-150.

Marull, J., Pino, J., Tello, E., Cordobilla, M.J., 2010. Social metabolism, landscape change and landuse planning in the Barcelona Metropolitan Region. Land use policy 27, 497-510. doi:10.1016/j.landusepol.2009.07.004

Marull, J., Tello, E., 2010. Land efficiency: The synergy between energy and landscape. Medi Ambient. Tecnol. i Cult. 108-112.

Marull, J., Tello, E., Bagaria, G., Font, X., Cattaneo, C., Pino, J., 2018. Exploring the links between 
social metabolism and biodiversity distribution across landscape gradients: a regional-scale contribution to the land-sharing versus land-sparing debate. Sci. Total Environ.

Mayumi, K., 1991. Temporary emancipation from land: from the industrial revolution to the present time. Ecol. Econ. 4, 35-56.

Meier, T., Christen, O., 2013. Environmental impacts of dietary recommendations and dietary styles: Germany as an example. Environ. Sci. Technol. 47, 877-888. doi:10.1021/es302152v

Meyer, B.C., Lescot, J.M., Laplana, R., 2009. Comparison of two spatial optimization techniques: A framework to solve multiobjective land use distribution problems, Environmental Management. doi:10.1007/s00267-008-9225-0

Millenium Ecosystem Assessment (MEA), 2005. Ecosystems and human well-being: Current state and trends. Island Press.

Moragues-Faus, A., Morgan, K., 2015. Reframing the foodscape: the emergent world of urban food policy. Environ. Plan. A 47, 1558-1573. doi:10.1177/0308518X15595754

Murray C., L., 2009. The carrying capacity imperative: assessing regional carrying capacity methodologies for sustainable land-use planning, in: 53rd Annual Meeting of the International Society for the Systems Sciences. Queensland.

North, D., 1961. The Economic Growth of the United States, 1790-1860. Prentice-Hall, Englewood Cliffs, N.J.

Olarieta, J.R., Padró, R., Masip, G., Rodríguez-Ochoa, R., Tello, E., 2011. “Formiguers”, a historical system of soil fertilization (and biochar production?). Agric. Ecosyst. Environ. 140, 27-33. doi:10.1016/j.agee.2010.11.008

Olarieta, J.R., Rodriguez Valle, F.L., Tello, E., 2006. Conservando y destruyendo suelos, transformando paisajes. El factor edáfico en los cambios de uso del territorio (el Vallès, Cataluña, 1853-2004 ). Areas 25, 76-103.

Padró, R., Marco, I., Cattaneo, C., Caravaca, J., Tello, E., 2017. Does your landscape mirror what you eat? Long-term socio-metabolic analysis of a local food system in the Vallès County (Spain, 1860-1956-2000), in: Frankova, E., Haas, W., Singh, S.J. (Eds.), In Search of Sustainable Local Food Systems: Socio-Metabolic Perspectives. Springer, New York.

Pascual P., 2009. Agricultura i industrialització a la Catalunya del segle XIX. Barcelona: Critica. Peters, C.J., Wilkins, J.L., Fick, G.W., 2007. Testing a complete-diet model for estimating the land resource requirements of food consumption and agricultural carrying capacity: The New York State example. Renew. Agric. Food Syst. 22, 145-153. doi:10.1017/S1742170507001767

Pimentel, D., Hurd, L.E., Bellotti, A.C., Forster, M.J., Oka, I.N., Sholes, O.D., Whitman, R.J., 1973. Food production and the energy crisis. Science (80-. ). 182, 443-449.

Planas, J., 2015. Expansió i crisi de la vinya al Vallès (1860-1940). Rev. del Cent. d’Estudis Granollers 19, 109-150. 
Polanyi, K., 1944. The great transformation: The Political and Economic Origins of Our Time. Beacon Press.

Roca, P., 2007. Agricultura i ramaderia en les masies del Vallès Occidental (1670-1830). Inedit research.

Roca, P., 1997. Aprofitaments col·lectius i revolució burgesa als boscos del Vallès Occidental (18271840). Terme 12, 58-65.

Rodriguez Valle, F.L., 2003. Evaluacion agricola de cinco municipios del Vallès en la situacion actual e historica de finales de siglo XIX. Universitat de Lleida.

Sadeghi, S.H.R., Jalili, K., Nikkami, D., 2009. Land use optimization in watershed scale. Land use policy 26, 186-193. doi:10.1016/j.landusepol.2008.02.007

Sahlins, M., 1971. The Intensity of Domestic Production in Primitive Societies: Societal Inflections on the Chayanov Slope, in: Dalton, G. (Ed.), Studies in Economic Anthropology. American Anthropological Association, Washington.

Sayer, J., Sunderland, T., Ghazoul, J., Pfund, J.-L., Sheil, D., Meijaard, E., Venter, M., Boedhihartono, A.K., Day, M., Garcia, C., van Oosten, C., Buck, L.E., 2013. Ten principles for a landscape approach to reconciling agriculture, conservation, and other competing land uses. Proc. Natl. Acad. Sci. 110, 8349-8356. doi:10.1073/pnas.1210595110

Seppelt, R., Voinov, A., 2003. Optimization methodology for land use patterns - Evaluation based on multiscale habitat pattern comparison. Ecol. Modell. 168, 217-231. doi:10.1016/S03043800(03)00138-8

Smit, B., 1981. Procedures for the long-term evaluation of rural land. Guelph.

Soroa, J., 1953. Prontuario del agricultor y el ganadero, 8th ed. Dossta, Madrid.

Stewart, T.J., Janssen, R., Van Herwijnen, M., 2004. A genetic algorithm approach to multiobjective land use planning. Comput. Oper. Res. 31, 2293-2313. doi:10.1016/S0305-0548(03)00188-6

Stoate, C., Báldi, A., Beja, P., Boatman, N.D., Herzon, I., van Doorn, A., de Snoo, G.R., Rakosy, L., Ramwell, C., 2009. Ecological impacts of early 21st century agricultural change in Europe - A review. J. Environ. Manage. 91, 22-46. doi:10.1016/j.jenvman.2009.07.005

Tello, E., 1990. Vendre per pagar. La comercialització forçada a l’Urgell I la Segarra a finals del segle XVIII. Recerques 23: 141-160.

Tello, E., Galán, E., Sacristán, V., Cunfer, G., Guzmán, G.I., González de Molina, M., Krausmann, F., Gingrich, S., Padró, R., Marco, I., Moreno-Delgado, D., 2016. Opening the black box of energy throughputs in farm systems: A decomposition analysis between the energy returns to external inputs, internal biomass reuses and total inputs consumed (the Vallès County, Catalonia, c.1860 and 1999). Ecol. Econ. 121, 160-174. doi:10.1016/j.ecolecon.2015.11.012

Tello, E., Garrabou, R., Cussó, X., Olarieta, J.R., Galán, E., 2012. Fertilizing Methods and Nutrient Balance at the End of Traditional Organic Agriculture in the Mediterranean Bioregion: Catalonia 
(Spain) in the 1860s. Hum. Ecol. 40, 369-383. doi:10.1007/s10745-012-9485-4

Tello, E., González de Molina, M., 2017. Methodological Challenges and General Criteria for Assessing and Designing Local Sustainable Agri-Food Systems: A Socio-Ecological Approach at Landscape Level, in: Socio-Metabolic Perspectives on the Sustainability of Local Food Systems Insights for Science, Policy and Practice. Springer-Verlag, New York, pp. 1-44.

Tilman, D., Clark, M., 2014. Global diets link environmental sustainability and human health. Nature 515, 518-522. doi:10.1038/nature13959

Tittonell, P., 2014. Ecological intensification of agriculture-sustainable by nature. Curr. Opin. Environ. Sustain. 8, 53-61. doi:10.1016/j.cosust.2014.08.006

Van der Ploeg, J., 2014. Peasants and the Art of Farming: A Chayanovian Manifesto. Practical Action Publishing, Rugby.

Van Kernebeek, H.R.J., Oosting, S.J., Van Ittersum, M.K., Bikker, P., De Boer, I.J.M., 2016. Saving land to feed a growing population: consequences for consumption of crop and livestock products. Int. J. Life Cycle Assess. 21, 677-687. doi:10.1007/s11367-015-0923-6

Vicedo, E., Colomé, J., Saguer, E., 2002. Las condiciones de reproducción económica de las unidades familiares campesinas en Cataluña a mediados del siglo XIX, in: Martínez Carrión, J.M. (Ed.), El Nivel de Vida En La España Rural, Siglos XVIII-XX. Universidad de Alicante, Alicante, pp. 321-358.

Wezel, A., H. Brives, M. Casagrande, C. Clément, A. Dufour, and P. Vandenbroucke. 2016. Agroecology territories: Places for sustainable agricultural and food systems and biodiversity conservation. Agroecol. Sust. Food Syst. 40 (2):132-44

Zhang, Y., 2013. Urban metabolism: A review of research methodologies. Environ. Pollut. 178, 463473. doi:10.1016/j.envpol.2013.03.052 


\section{SUPPLEMENTARY MATERIAL: THE LINEAR OPTIMIZATION PROGRAMME}

We present below the data and assumptions of the linear optimization programme used. To this end, we draw on the main variables that define the size of the farm. Then we explain the assumptions and boundary conditions of the three funds considered: Domestic Unit (DU), livestock and farmland. Subsequently, we specify the constraints given by biophysical conditions as well as cultural factors, presenting them according to the fund they correspond to.

The time frame considered to run the programme is a whole year. This does not contradict a dynamic view of the agroecosystem functioning. Farmers' decisions are ever changing over time, and so do the natural processes they are coproducing with. Hence, flow interactions among these funds will be different from one year to another. The data taken to specify the variables, parameters and constrains of the linear programming model are average values that usually averaged the oscillations of the last five years. Yet, in order to ensure sustainability for the years to come the needs of these funds had to be met within those average values of the annual flows considered.

\section{Funds and boundary conditions}

Once the main variables are defined, we have to characterize the dimension of the soil fund (in terms of surface area) by setting the assumptions and boundary conditions that affect the size of the three main funds of an agroecosystem: Domestic Unit, livestock and non-domesticated species. We consider boundary conditions to be the dimension of DU and livestock, while the optimization will be regarding the total surface of farmland. This is reasonable for the domestic unit (DU), as its composition was a socio-cultural condition, but not for livestock density ${ }^{5}$. Therefore, we will have to double check whether in an optimized scenario it would be better to increase or decrease the livestock component. In further methodological developments, this issue will be solved using non-linear optimization.

\footnotetext{
${ }^{4}$ The code is available upon request.

${ }^{5}$ The dimension of the Domestic Unit depended on the available farmland surface, and was also defined by social traditions and conditions. Indeed, if we run the model asking for the minimum surface required to reproduce an agroecosystem, the dimension of Domestic Unit will always be one average person. Conversely, there was no apparent limitation on having more or less livestock in a farm other than the corresponding feed requirement, and our model sets no restrictions on this as long as they were locally bred species.
} 


\subsection{Domestic Unit (DU)}

From the 1860 municipal population census of Sentmenat we obtain the average domestic structure, counting both family and non-family members (servants), of the 191 farms of which we have specific information on their composition. Average was 5.08 people per DU, median was 5 people, and 4 people the modal. We will take 5 people on average for each Domestic Unit (DU).

Once we analysed the 30 DU with 5 individuals, their modal composition included a girl between 0 , a boy from 5 to 10, a man between 18 and 60, a woman between 18 and 60, and a man over 60 years old. This will be our average DU, and its structure affects in our SAFRA model the consumption of food (regarding each type of diet),the work capacity, and the monetary requirements for clothes and shoes (as will be seen later in terms of constraints).

This DU structure fits the Consumers/Workers ratio that existed at municipal level. Yet, in order to avoid an overestimation of farmland capacity, and to extrapolate results at municipal level, we need to verify as well that this composition corresponds to the maximum requirement of surface throughout the family live cycle. Thus, we calculate the Minimum Reproduction Unit (MRU; i.e., the most variable scenario regarding this boundary condition) for the five stages of the family life cycle that we defined in Table 2. The modal composition presented above corresponds to stage 2.

Table 2.Scenarios of evolution of the family structure; $W$ indicates woman and $M$ man. Data in years

\begin{tabular}{cccccc} 
Stage & $\mathbf{1}(\boldsymbol{W})$ & $\mathbf{2}(\boldsymbol{M})$ & $\mathbf{3}(\boldsymbol{W})$ & $\mathbf{4}(\boldsymbol{M})$ & $\mathbf{5}(\boldsymbol{M})$ \\
\hline S1 & - & - & 20 & 24 & - \\
\hline S2 & 2 & 7 & 30 & 34 & 65 \\
\hline S3 & 12 & 17 & 40 & 44 & - \\
\hline S4 & 22 & - & 50 & 54 & - \\
\hline S5 & - & - & 60 & 64 & - \\
\hline
\end{tabular}

Source: Our own, based on the sources detailed in the text.

Once we run the MRU model in these 5 stages, the resulting profile in terms of required land surface is the one indicated in Figure 1. As can be seen, stage 2 was the one that required the greater surface. Therefore, regardless of whether this stage is taken to represent the evolution at municipal level, the result will be suitable for the whole family cycle (that is, a complete generation). 


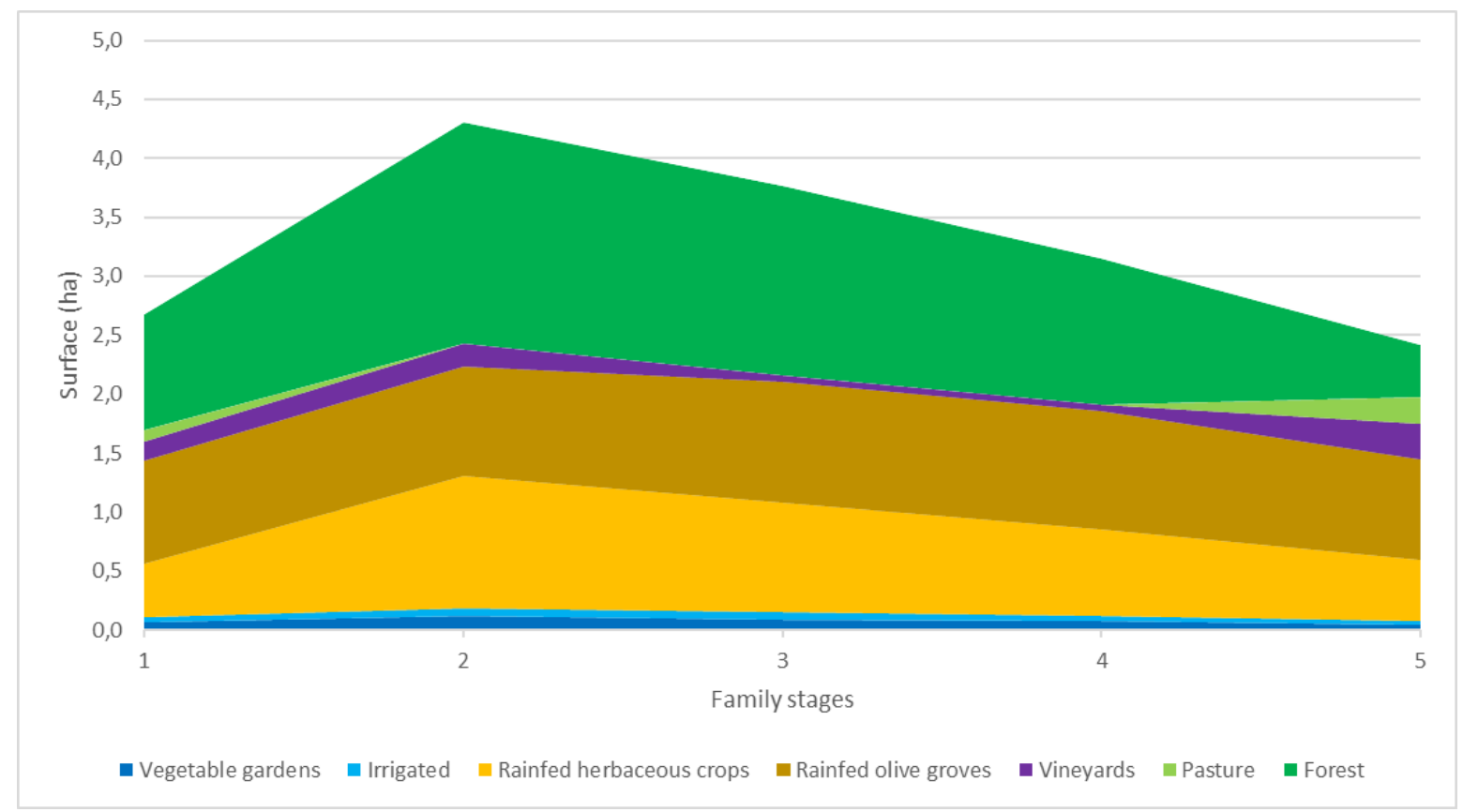

Figure 1.Evolution of the surface required in MRU according to the family live cycle. Source: Our own, based on the sources detailed in the text

In order to be able to extrapolate the results at municipal scale, we have to take into account the different DU compositions within the whole population. Therefore, we weighted the results based on the number of people in the UD. For that purpose, we define the $Z$ parameter, which is an integer value according to the number of individuals in the farm. As indicated above, at farm scale analysis we use as a reference $Z=5$. Notwithstanding, when extrapolating the potential development at municipal level results are weighted according to the distribution of frequencies for each composition of DU. Frequency distribution in Sentmenat c.1855 is presented in Figure 2.

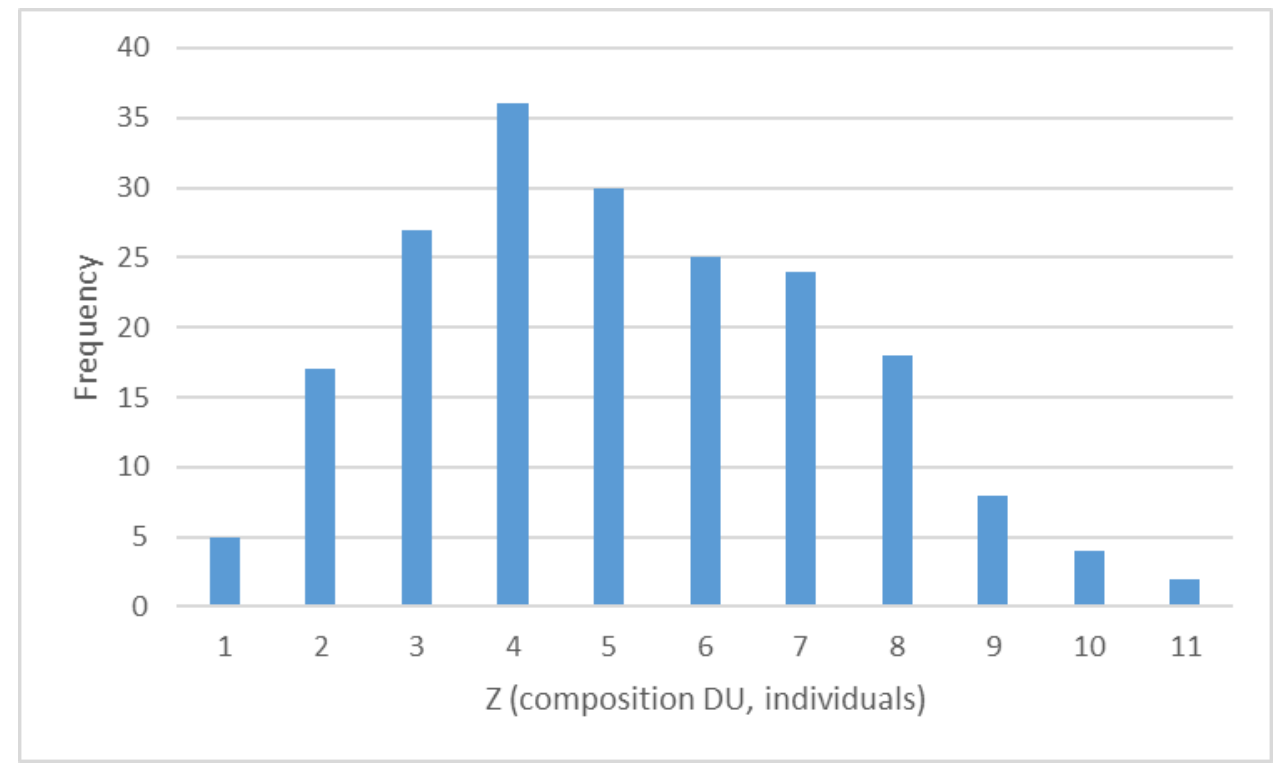

Figure 2.Frequency of DU for each composition

Source: Our own, based on the sources detailed in the text. 


\subsection{Livestock}

As indicated in the article, we distinguish between two types of domestic animals: meat and dairy producing animals, and draught animals. We base their dimension on the other two funds. Meat and dairy producing animals, or consumption animals, depend on the size of the DU (Z), while draught animals depend on the amount of land to be ploughed and tilled (cropland area) according to the prevailing farm management in the Vallès County at that time (Roca, 2007).

For consumption animals we consider that a family of 5 people had 1 rabbit, 2 chickens, 2 hens and 1 pig (Marco et al., 2017). We included ovine and caprine heads as well into these consumption animals. At municipal level, according to the livestock census of 1860, there were 2,835 units, which once distributed among DUs represented 1.6 units/DU. We rounded up that value to 2 animals/DU, which would be sheep as it was the most common meat consumed in those rural areas.

For draught animals we consider that smallholder farms shared mules (the predominant ones according to the livestock census of 1860), meaning that their feeding was proportional to the farmland area possessed (Roca, 2007). Since Sentmenat had an standardized weight of draught animals of 115.8 LU500, if we divide this among the 1,757 ha of cropland area we get 0.1011 mules/ha. We define a parameter $M$ that indicates the estimated livestock density endowment (in terms of mule sharing; Eq.2). Therefore, we multiply $M$ by the total surface of the farm.

$$
\begin{aligned}
& M=0.1011\left(X_{1}+X_{2}+X_{2}+X_{4}+X_{6}+X_{9}+X_{9}+X_{10}+X_{11}+X_{12}+X_{19}+X_{14}+X_{15}+X_{16}+X_{17}+\right. \\
& \left.X_{18}\right)
\end{aligned}
$$

\subsection{Farmland}

We assume in our reproductive model that data on productivity provided by sources respond to a static equilibrium. Therefore, as long as farmers ensured nutrients replenishment, land productivity would have kept steady. Land productivity data has been taken from the Estudio Agrícola del Vallès of 1874 (Garrabou and Planas, 1998), and the estimates of all its by-products through ratios compiled in Guzmán et al., (2014). Data is about the edible fraction, once the required seed for the coming year was subtracted.

\section{Constraints}

General constraints fix the relationship between the total area of a land use, and the directions each product or by-product obtained in this use can take. These constraints all take a similar configuration, as indicated in Eq.1 (where $X_{i}$ is the surface of a specific use (along $X_{1}$ and $X_{22}$ ), and $X_{i, j, k}$ the share of this surface $i$, the product $j$ of which is going in the direction $j$ ). The same would happen with $Y_{l, m, n}$

\footnotetext{
${ }^{6}$ As can be seen on the total surface area cultivated, neither $X_{5}, X_{7}$ nor $X_{18}$ appear in the formula. The reason is that their areas are accounted in other uses or vice versa, as indicated in section 3.1 of this Supplementary Material.
} 


$$
X_{\mathrm{i}}=\sum_{k=1}^{k=n} X_{\mathrm{i}, j k} \text { where } X_{\mathrm{i}, j, j k} \geq 0 \text { (Eq.3) }
$$

\subsection{Constraints for farmland}

We start with the constraints that affect the agrological capacities of the cultivated land at municipal level, taking the site-specific cultural practices into account. For this section, we use the information given in the municipal land-use register (Amillaramiento) of 1859 on the extent of each soil quality, as well as the crop rotation systems described in the Estudio agrícola del Vallés of 1874 (Garrabou and Planas, 1998). 


\subsubsection{Distribution of soil quality in the municipality}

For land uses that appear in more than one quality, we define general constraints for irrigated wheat (characterized by $\left.X_{4}\right)$, dryland wheat $\left(X_{8}\right)$, rye \& wheat mixture $\left(X_{11}\right)$, potatoes $\left(X_{14}\right)$, olive tree groves $\left(X_{18}\right)$, vineyards $\left(X_{19}\right)$ and forest $\left(X_{22}\right)$.

As well, we include specific equations corresponding to the first and second soil quality surfaces, so that their distribution does not overestimate the productive capacity of each type of land unit in the territory. This allows the results obtained as yields per unit of land to be extrapolated at municipal scale

Here it is important to explain a relevant assumption regarding soil quality. We assumed that each soil quality registered by crops is interchangeable to other uses. While this could be true for dryland crops and vines it is less suitable for a change from forest to dryland crop. Indeed, from a historical perspective, land intensification in the area was mainly driven by the emphyteutic rabassa morta contracts. There, forest areas where leased to poor farmers who had to clear forest and plant vineyards. Very often those areas where in steep land, and farmers were forced to build terraces so as to protect them from erosion. Fieldwork done in a neighbouring municipality Olarieta et al., (2008) recorded that around $43 \%$ of cropped area required landesque capital investments in the form of terraces and soil conservation practices. Therefore, the assumption that steep forest areas could be cropped despite their agrological low value seems to be reasonable in a context of those unequal land-use intensification practices. Finally, the results obtained in the extreme value of MSS(3) would have meant changing the use of 416 additional hectares of forest and pastures into vineyards. However, as presented in table 4, c.1860 there were still more than 430 ha below a slope of 30\%, and 770 ha below $60 \%$. Therefore, due to this 'free labour' that farmers had to invest in constructing terraces, and considering that there was still room for planting more vineyards in areas with less slope, we consider reasonable to validate as technologically feasible the extreme scenario in terms of total cropland area.

Table 4.Distribution of forest in Sentmenat by slope c.1860

\begin{tabular}{cc} 
Slope (\%) & Surface (ha) \\
\hline $\mathbf{0 - 1 0}$ & 143.6 \\
\hline $\mathbf{1 0 - 2 0}$ & 145.0 \\
\hline $\mathbf{2 0 - 3 0}$ & 149.7 \\
\hline $\mathbf{3 0 - 6 0}$ & 332.0 \\
\hline$>\mathbf{6 0}$ & 63.7 \\
\hline Source: Our own, based on the sources detailed in the text.
\end{tabular}

\subsubsection{Total irrigated surface and total farm surface}

In order to ensure the adequacy of results to the edaphic capabilities we include two additional boundary conditions. For this purpose we consider that the whole irrigated area that existed, according 
to the municipal land tax register sources of Sentmenat, was the maximum possible irrigated land under those cultural practices and available technologies. So, the amount of land used with this irrigated crop rotation has to represent in the farm-type considered the same percentage as at the municipal level. With a total surface of 42.54 ha over the 2,781 ha of farmland, that proportion was $1.53 \%$

\subsubsection{Crop rotations}

The rotation for irrigated lands implied tilling more than a crop a year. Wheat $\left(X_{4}\right)$ was followed after harvested, within the same year, by corn $\left(X_{5}\right)$ sown in half of the land, while the other half was left in fallow $\left(X_{20}\right)$. The same happened after hemp $\left(X_{6}\right)$ and beans $\left(X_{7}\right)$ for the second year. Thus, the total irrigated area will be expressed by the sum between $X_{4}$ and $X_{6}$, amounting $X_{5}, X_{7}$ and $X_{20}$ the same surface as the former. We do not count as total surface the latter, because crop is produced within the same space although at different moments along one year.

In the herbaceous dryland there was also a rotation for each soil quality. In the first one there was a biennial rotation of wheat and beans; in the second one it was of wheat and forage, and in the third of rye \& wheat mixture and vetches

The cultivation of olive trees was associated to various grains intercropped in between the rows of trees according to the soil quality. Land productivities of the original historical sources contemplated that farmers cultivated olive trees and other herbaceous crops simultaneously, as an associated silvoarable farming. This means that both perennial and annual crops were grown on the same land at the same time, so total olive groves' rotation area will be either $X_{18}$ or the sum of all the associated crops. . 


\subsection{Constraints for livestock breeding}

Regarding livestock feeding, the model begins from the energy requirements of each type of animal accounted as metabolizable energy (ME). The energy needs of animals are primarily estimated from Church (1984), as well as using other secondary sources (Brenes et al., 1978; Burden, 2012; Giménez, 1994; National Research Council, 1989) from which we estimate the requirements shown in Table 5.

Table 5.Animal energy requirements

\begin{tabular}{|c|c|c|c|}
\hline & & \multicolumn{2}{|c|}{ Energy requirements } \\
\hline & & $\begin{array}{r}\text { Daily } \\
\text { (Kcal/day) }\end{array}$ & $\begin{array}{l}\text { Annuals } \\
\text { (MJ/year) }\end{array}$ \\
\hline les & $\mathrm{Mu}$ & 12,491 & 19,076 \\
\hline еер & Sh & 1,567 & 2,393 \\
\hline ns & He & 356 & 544 \\
\hline ckens & Chi & 269 & 411 \\
\hline bbits & $\mathrm{Ra}$ & 317 & 317 \\
\hline S & Pig & 3,900 & 5,956 \\
\hline
\end{tabular}

We therefore identify which resources were suitable for feeding each animal, following the criteria indicated below:

- Straw and stubble: Includes wheat stump, hoof and stubble (from dryland, irrigated, associated to olive tree groves and mixed with rye), and the same with barley. We consider all animals suitable for consuming straw, with the exception of pigs, poultry and rabbits.

- Grain: A part of the main production was destined to animal feeding. Included barley, corn and legumes (dryland and irrigated beans, vetches and lupines). It was suitable for all animals.

- Horticultural by-products: We estimate its composition from a mixture of the leftovers of various vegetables (pumpkin, beans, lettuce, turnips, tomatoes and carrots). They were used to feed pigs, poultry and rabbits.

- Pomace of vine grapes and olives: Farmers also used pomaces for feeding pigs, poultry and rabbits.

- Olive tree browsing: These were the tender shoots of olive trees, which farmers used to feed herds, mainly of pigs.

- Fodder: Draught animals, as well as sheep, complemented their feeding with such kind of production.

- Domestic residues: They were the basis for the feeding of chickens, hens, rabbits and pigs.

- Oak acorns from forest: In the case of pigs, we consider that a relevant part of its feeding came from grazing in oak forests. 
- Grazing in pastures and forests: Sheep, but also draught animals, where fed using grazing lands.

In order to know the contribution in terms of metabolizable energy of each possible kind of feed, Table 6 shows its contribution per kg in dry and per animal. When some cells appear empty it means that this was an unsuitable feed, or not commonly used for the specific animals considered.

Table 6. Metabolizable energy values (MJ/kg of dry matter) regarding kinds of feeds and species

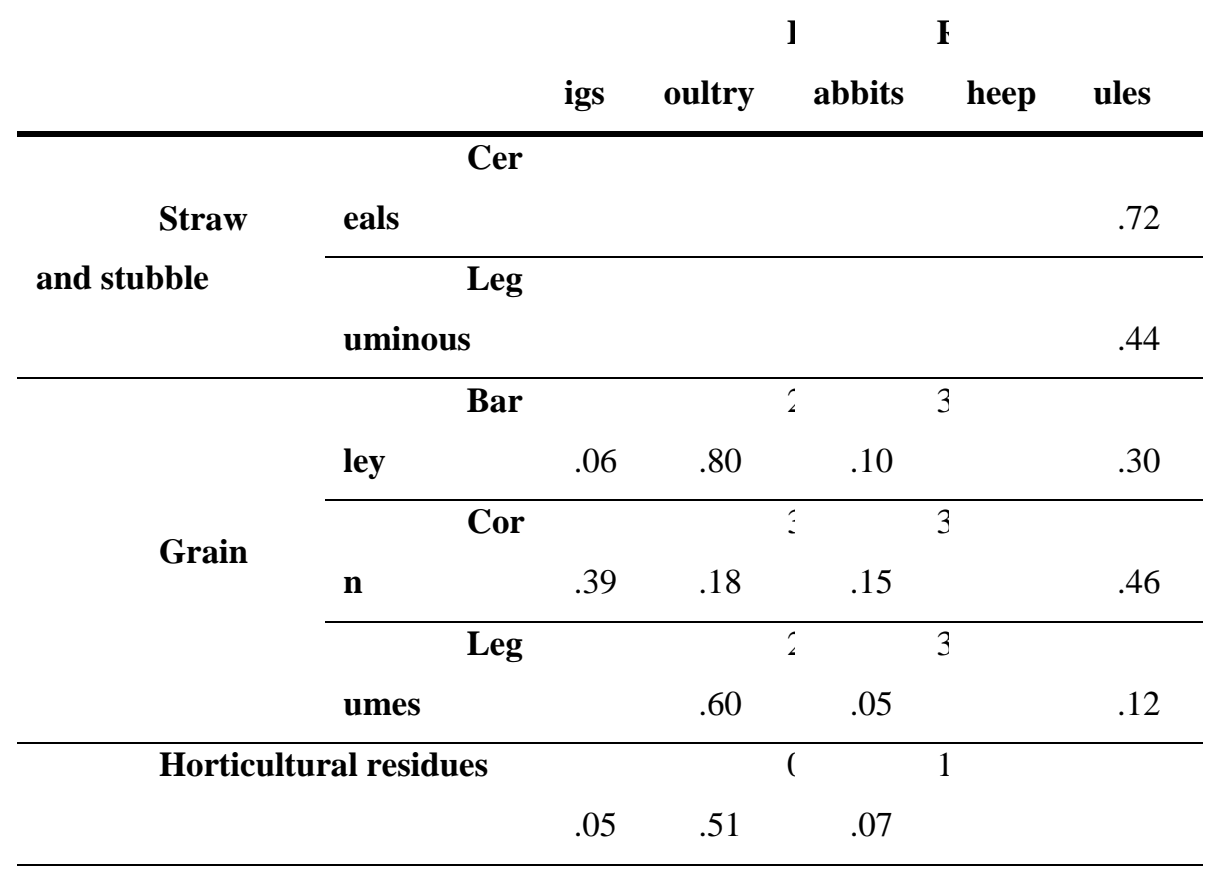

Olive oil pomace

.71

Grapevine pomace

.71

Olive tree browsing

.48

\begin{tabular}{|c|c|c|c|c|c|}
\hline \multicolumn{6}{|l|}{ Forages } \\
\hline & .71 & & & .36 & .36 \\
\hline \multirow[t]{2}{*}{ Domestic residues } & & & & 1 & \\
\hline & .25 & .00 & .50 & & \\
\hline
\end{tabular}

\section{Oak acorns}

.08

\begin{tabular}{lll}
\hline Pasture & & \\
& .15 & .46 \\
\hline
\end{tabular}

Source: Our own, based on the sources detailed in the text.

Once the variables are defined in terms of productivities, moisture and energy content of each feed, we proceed to perform the specific constraints of animal feeding for each species. In some cases, we 
include physiological limitations based on the maximum recommended shares in the diet of certain kinds of products (FEDNA, 2010).

We define several constraints for mules. First, on the one hand, the inclusion of the $M$ parameter requires fixing a constraint according to which the pasture consumption is less than the total consumption of feed. On the other hand, fodder cannot account for more than 45\% of diet (Eq.53), and cereal straw must reach a maximum of $25 \%$.

Regarding stall bedding, tt is also necessary to consider the amount of crop by-products needed. Using Soroa (1953) as historical source, we assume that mules required $2 \mathrm{~kg}$ of stall bedding per day, 0.2 $\mathrm{kg} /$ day for sheep, and $1.5 \mathrm{~kg} /$ day for pigs and. From UPAE (2011) we assume for poultry and rabbits $1.25 \mathrm{~kg} /$ year.

Finally, we use data on the working capacity of draught animal power assuming an average working period of 220 days/year. Sources are the same ones used for labour in section 2.4.3.

\subsection{Constraints for maintaining soil chemical fertility}

With respect to the flows needed for soil fertility maintenance, we divide the whole cropland surface among 5 different crop systems, mainly based on crop rotations. These were: orchards and fruit trees, irrigated crops, herbaceous dryland crops, associated crops in olive tree groves, and vineyards. We consider three different kinds of cultural practices for fertilization, which were used for one or more of the different crop systems:

- Application of humanure: We consider that its application was limited to vegetable gardens, irrigated crops and herbaceous dryland, which were located on the lands closest to the farmhouse.

- Application of animal manure with its corresponding beds: These were applied in all crops except for vegetable gardens and fruit tree orchards where we assume they were not necessary.

- Burying biomass: It is known that the burial of biomass was a common practice, and it was done both for all dry crops and in vineyards.

We characterize those practices regarding its fertilization potential, in terms of the main macronutrients (nitrogen, phosphorus and potassium) content.

Animal manure comprises two different phases: On the one hand animal excreta, and on the other hand stall beds on which this excreta remains. It is a rather complex issue to decide the composition of animal feeding, given that the actual collection of excreta depended on the number of days animals grazed. We assume that all the flows of feeding were obtained at municipal scale in 1860 (Marco et al., 2017). Thus, we consider the amount of excreta, moisture and grazing days, and its composition in N, $\mathrm{P}$ and $\mathrm{K}$ in $\mathrm{kg}$ of fresh matter taken from the American Society of Agricultural Engineers (ASAE, 2000). Assuming that livestock was $100 \%$ of the days of a year grazing, only $45 \%$ of excreta could be collected by means of locking the animals in pens at night (Cascón, 1918). Hence, the actual factor of 
manure application was also determined by considering their grazing period. We show the results in Table 8.

For the case of mules, and given its relevance and multiple possibilities of their feed intake, we generate a $P$ parameter in order to define the percentage of manure collected from the total. This $P$ depends in turn on a parameter $D$, which is the number of grazing days.

Table 8.Animal excreta composition

\begin{tabular}{|c|c|c|c|c|c|c|c|}
\hline \multirow[t]{2}{*}{ Animal } & \multicolumn{5}{|l|}{ Excreta } & \multicolumn{2}{|c|}{ Pasture } \\
\hline & Production & Moisture & Nitrogen & Phosphorus & Potassium & Days & Collected \\
\hline & kg/day & $\%$ & & \% fresh matt & & & $\%$ total \\
\hline Mules & 14.64 & 70.59 & 0.59 & 0.14 & 0.49 & $D$ & $P$ \\
\hline Sheep & 1.20 & 72.50 & 1.05 & 0.22 & 0.80 & 365 & 45.00 \\
\hline Pigs & 9.47 & 86.90 & 0.62 & 0.21 & 0.35 & 105 & 84.18 \\
\hline Hens & 0.31 & 75.00 & 1.31 & 0.35 & 0.47 & 0 & 100 \\
\hline Chickens & 0.23 & 74.12 & 1.29 & 0.35 & 0.47 & 0 & 100 \\
\hline Rabbits & 0.18 & 74.12 & 1.29 & 0.35 & 0.47 & 0 & 100 \\
\hline
\end{tabular}

Source: Our own, based on the sources detailed in the text.

To run everything off, we calculate the replenishment requirements for each land use through nutrient balances, mainly following the criteria proposed by González de Molina et al. (2010). The results are presented in Table 10. 
Table 10.Requirements in terms of $\mathrm{N}, \mathrm{P}$ and $\mathrm{K}(\mathrm{kg} / \mathrm{ha})$ for the different land uses, regarding its soil quality

\begin{tabular}{|c|c|c|c|c|}
\hline & Soil Quality & $\mathbf{N}$ & $\mathbf{P}$ & $\mathbf{K}$ \\
\hline Vegetable gardens & & 51.00 & 3.42 & 11.43 \\
\hline Fresh fruits in orchards & & 8.35 & -2.07 & -4.88 \\
\hline Nuts & & 26.63 & 0.23 & 2.97 \\
\hline \multirow{3}{*}{ Irrigated wheat } & 1 & 42.43 & 6.15 & 15.34 \\
\hline & 2 & 34.25 & 4.88 & 11.84 \\
\hline & 3 & 23.35 & 3.19 & 7.17 \\
\hline \multirow{3}{*}{ Irrigated corn } & 1 & 28.03 & 4.00 & 8.95 \\
\hline & 2 & 21.98 & 3.11 & 6.83 \\
\hline & 3 & 15.94 & 2.22 & 4.71 \\
\hline \multirow{3}{*}{ Irrigated hemp } & 1 & 45.84 & -0.05 & 0.70 \\
\hline & 2 & 41.82 & -0.28 & -0.18 \\
\hline & 3 & 37.80 & -0.51 & -1.07 \\
\hline \multirow{3}{*}{ Irrigated beans } & 1 & -23.72 & 5.43 & 20.38 \\
\hline & 2 & -21.68 & 4.01 & 15.01 \\
\hline & 3 & -19.65 & 2.58 & 9.64 \\
\hline Wheat & \multirow{3}{*}{1} & 41.46 & 6.31 & 5.30 \\
\hline Beans & & -4.60 & 3.65 & 1.98 \\
\hline Potatoes & & 13.41 & 1.34 & -1.58 \\
\hline Wheat & \multirow{3}{*}{2} & 30.56 & 4.61 & 0.64 \\
\hline Fodder & & 24.67 & 4.72 & 14.91 \\
\hline Potatoes & & 9.69 & 0.76 & -5.21 \\
\hline Rye \& wheat mixture & \multirow{2}{*}{3} & 21.51 & 3.21 & -3.27 \\
\hline Vetches & & -0.96 & 2.29 & 3.16 \\
\hline Associated wheat to olive trees & \multirow{2}{*}{1} & 27.45 & 3.73 & 11.04 \\
\hline Potatoes & & 17.76 & 1.62 & 10.14 \\
\hline Corn & \multirow{2}{*}{2} & 14.88 & 1.64 & 3.94 \\
\hline Rye \& wheat mixture & & 21.40 & 2.79 & 8.42 \\
\hline Barley & \multirow{2}{*}{2} & 18.79 & 2.10 & 10.49 \\
\hline Lupines & & 2.64 & 4.11 & 6.14 \\
\hline \multirow{3}{*}{ Olive oil } & 1 & 25.43 & 3.10 & -4.39 \\
\hline & 2 & 21.36 & 2.74 & -5.48 \\
\hline & 3 & 17.88 & 2.44 & -6.42 \\
\hline \multirow{3}{*}{ Vineyard } & 1 & 13.24 & 1.12 & -1.73 \\
\hline & 2 & 10.51 & 0.79 & -3.29 \\
\hline & 3 & 5.97 & 0.25 & -5.88 \\
\hline
\end{tabular}

Source: Our own, based on the sources detailed in the text. 


\subsection{Constraints for maintaining the Domestic Unit}

\subsubsection{Food intake}

When accounting for diets we will only consider food agroecosystems provided (that is, we exclude fish). Additionally, as already mentioned above, the model assumes that farmers could be free to obtain a perfect agrosilvopastoral mosaic to attain their self-sufficiency, as a counterfactual scenario to be contrasted with the actual situation in which they depended on exports, imports and the volatility of relative prices.

Indeed, historical sources confirm that most products included in the local diet came from the Vallès County. Peasant diets included mainly cereals, potatoes, legumes, oil and wine, with some products of animal origin (Cussó and Garrabou, 2000). Following the criteria of Marco et al. (2017b) we obtained an estimated average consumption for the average family unit of 5 people. Diet was mainly based on bread consumption, and potatoes to a lesser extent, contributing $70 \%$ and $12 \%$ respectively to daily intake. We show the results in Table 14.

Table 14.Food intake needs by our DU along a year

\begin{tabular}{lcccc} 
& $\begin{array}{c}\text { Per DU } \\
\text { (kg/day) }\end{array}$ & $\begin{array}{c}\text { Per year } \\
\text { and DU } \\
\text { (kg) }\end{array}$ & $\begin{array}{c}\text { Per year } \\
\text { and } \\
\text { person } \\
\text { (kg) }\end{array}$ & $\begin{array}{c}\text { Total } \\
\text { consumption } \\
\text { (kg/Z) }\end{array}$ \\
\hline Bread & 2.42 & 88.29 & 176.58 & 146.56 \\
\hline Olive oil $^{7}$ & 0.06 & 22.9 & 4.58 & 12.46 \\
\hline Wine & 0.40 & 146.8 & 29.37 & 29.37 \\
\hline Legumes & 0.12 & 43.5 & 8.70 & 8.70 \\
\hline Potatoes & 1.59 & 580.2 & 116.04 & 116.04 \\
\hline Vegetables & 0.86 & 315.3 & 63.06 & 63.06 \\
\hline Fresh fruit & 0.14 & 50.5 & 10.09 & 10.09 \\
\hline Nuts & 0.07 & 25.2 & 5.05 & 5.05 \\
\hline Meat & 0.13 & 45.7 & 9.14 & 9.14 \\
\hline \multicolumn{1}{c}{ Source: Our own, based on the sources detailed in the text. }
\end{tabular}

Therefore, crop distribution in a self-reproductive farm had to ensure that farmers could meet these nutritional needs. For meat we calculated that with the estimated livestock density our DU obtained the total of $65 \mathrm{~kg}$ a year of meat required for an average farm at that time, according to the historical sources available.

\subsubsection{Firewood for heating}

\footnotetext{
7 The model includes the use of oil for illumination. According to our estimates, based on population data given by Garrabou (1,686 people), we estimated the local oil consumption for food and a total dietary consumption. This was 8,833 litres out of the 23,827 litres of apparent consumption in the municipality. The difference (14,994 litres) is divided between the number of certificates of the same source (347). We obtain an annual consumption of 43.20 litres/DU, that is a daily consumption of 0.118 litres/UD or $0.108 \mathrm{~kg} / \mathrm{UD}$ we added in the food consumption data in the last column.
} 
It is also necessary to take into account that there were constraints on the provision of firewood and wood. So we obtained the partial constraint to the exosomatic firewood consumption by this rural community based on an estimated consumption of $1.56 \mathrm{~kg}$ of wood fuel per inhabitant per day, following the criteria of Marco et al. (2017). In addition, as pointed out by Colomé (2016, personal communication), the consumption of vine pruning was considered anecdotal and could not suppose more than $10 \%$ of fuel requirements of the DU.

\subsubsection{Labour}

In terms of labour, the constraint was that the working capacity of the family did not exceed the labour needs of all the farms in the municipality. To calculate this we took, on the one hand, data on labour requirements for crops, forest and livestock maintenance (Garrabou and Planas, 1998). On the other hand, to calculatr human labour capacity we used a monthly accounting to guarantee that there were no seasonal bottlenecks throughout the year.

a) Monthly labour capacity

We calculated the working capacity in the farm-type considered by estimating the ability of the 5 people taking gender and age into consideration. This implied a total availability of 580 workdays throughout a year. However, we decided to consider the working capacity also based on the variation of hours of sunlight along the year. We calculated total hours of sunlight per day, based on latitude data and solar radiation functions, as can be seen in Table 15. 
Table 15.Weighting factors concerning total hours of sunlight

\begin{tabular}{lccc} 
& $\begin{array}{c}\text { Daily hours } \\
\text { of sunlight }\end{array}$ & Factor & $\begin{array}{c}\text { Available } \\
\text { workdays } \\
(* \mathbf{Z})\end{array}$ \\
\hline January & 9.37 & 0.78 & 7.55 \\
\hline February & 10.39 & 0.87 & 8.37 \\
\hline March & 11.73 & 0.98 & 9.45 \\
\hline April & 13.15 & 1.10 & 10.60 \\
\hline May & 14.36 & 1.20 & 11.57 \\
\hline June & 14.96 & 1.25 & 12.05 \\
\hline July & 14.67 & 1.22 & 11.82 \\
\hline August & 13.61 & 1.13 & 10.96 \\
\hline September & 12.23 & 1.02 & 9.85 \\
\hline October & 10.80 & 0.90 & 8.70 \\
\hline November & 9.61 & 0.80 & 7.74 \\
\hline December & 9.03 & 0.75 & 7.28 \\
\hline Source: Our own, based on the sources detailed in the text
\end{tabular}

Source: Our own, based on the sources detailed in the text.

b) Monthly requirements by crop

We calculated requirements for each crop on a monthly basis by weighting the annual data given in Amillaramientos del Vallès with the monthly distribution patterns detailed in Garrabou et al. (1992). The available data contains monthly workdays per hectare for the Counties of Empordà (1850-1870, 1930-1936), La Segarra (1880-1890), Vic (1830-1840, 1880-1890, 1930-1950) and El Penedès (19031907), all of them in Catalonia. We present this data in Table 16. 
Table 16.Monthly requirements in workdays/ha

\section{Month}

\begin{tabular}{|c|c|c|c|c|c|c|c|c|c|c|c|c|c|}
\hline & 1 & 2 & 3 & 4 & 5 & 6 & 7 & 8 & 9 & 10 & 11 & 12 & Total \\
\hline Vegetable gardens & 6.1 & 61 & 85 & 13.6 & 15.3 & 15.3 & 18.8 & 18.8 & 17.0 & 10.0 & 68 & 6.1 & 142.4 \\
\hline Fresh fruits & 0.0 & 33 & 00 & 0.0 & 0.0 & 1.9 & 1.9 & 5.3 & 5.3 & 0.0 & 00 & 0.0 & 17.7 \\
\hline Nuts & 0.0 & 33 & 00 & 0.0 & 0.0 & 1.9 & 1.9 & 5.3 & 5.3 & 0.0 & 00 & 0.0 & 17.7 \\
\hline Wheat & 0.0 & 49 & 87 & 2.4 & 0.0 & 4.8 & 14.1 & 3.9 & 1.9 & 5.3 & 34 & 0.0 & 49.5 \\
\hline Corn & 0.0 & 42 & 73 & 1.0 & 9.1 & 7.2 & 0.0 & 4.4 & 1.9 & 8.3 & 00 & 8.7 & 52.0 \\
\hline Hemp & 18.2 & 00 & 261 & 5,3 & 3.3 & 3.3 & 3.3 & 3.3 & 14.4 & 13.8 & 401 & 62.6 & 193.7 \\
\hline Beans & 9.2 & 91 & 00 & 9.1 & 0.0 & 10.6 & 4.8 & 0.0 & 12.8 & 0.0 & 80 & 1.5 & 65.1 \\
\hline Wheat & 0.0 & 49 & 88 & 2.5 & 0.0 & 4.8 & 14.2 & 3.9 & 2.0 & 5.4 & 34 & 0.0 & 50.0 \\
\hline Associated wheat & 0.0 & 50 & 90 & 2.5 & 0.0 & 4.9 & 14.5 & 4.0 & 2.0 & 5.5 & 35 & 0.0 & 51.0 \\
\hline Corn & 0.0 & 42 & 73 & 1.0 & 9.1 & 7.2 & 0.0 & 4.4 & 1.9 & 8.4 & 00 & 8.8 & 52.3 \\
\hline Rye \& wheat mixture & 0.0 & 62 & 97 & 4.2 & 0.0 & 4.2 & 9.6 & 3.4 & 2.9 & 4.7 & 35 & 0.0 & 48.3 \\
\hline Barley & 0.0 & 21 & 42 & 2.1 & 0.0 & 4.7 & 14.3 & 14.7 & 3.0 & 2.5 & 04 & 0.0 & 48.1 \\
\hline Fodder & 5.2 & 52 & 57 & 0.0 & 8.6 & 4.4 & 7.4 & 5.9 & 3.9 & 3.9 & 00 & 0.0 & 50.2 \\
\hline Potatoes & 0.0 & 00 & 149 & 0.0 & 6.4 & 6.4 & 0.0 & 0.0 & 35.5 & 10.6 & 52 & 0.0 & 79.0 \\
\hline Beans & 9.2 & 91 & 00 & 9.1 & 0.0 & 10.6 & 4.8 & 0.0 & 12.8 & 0.0 & 80 & 1.5 & 65.1 \\
\hline Vetches & 9.2 & 91 & 00 & 9.1 & 0.0 & 10.6 & 4.8 & 0.0 & 12.8 & 0.0 & 80 & 1.5 & 65.1 \\
\hline Lupines & 9.2 & 91 & 00 & 9.1 & 0.0 & 10.6 & 4.8 & 0.0 & 12.8 & 0.0 & 80 & 1.5 & 65.1 \\
\hline Olive trees & 6.8 & 00 & 149 & 14.9 & 12.2 & 5.4 & 0.0 & 0.0 & 0.0 & 0.0 & 00 & 27.1 & 81.2 \\
\hline Vineyards & 0.0 & 00 & 51 & 13.1 & 4.7 & 5.0 & 0.6 & 0.0 & 1.8 & 12.0 & 11 & 0.0 & 43.4 \\
\hline
\end{tabular}

Source: Our own, based on the sources detailed in the text.

Regarding the care of livestock, there is a minimum of 35.5 workdays/year per mule and 27.87 workdays/year for the rest of livestock for a $Z=5$.

We add to these labour requirements the ones required by cropland fertilization, according to each type of fertilizing management, and using estimates from Soroa (1953). However, not all fertilization tasks took place in the same months. Thus, they are distributed based on cultivation schedules defined in Garrabou et al. (2012). 


\subsubsection{Monetary requirements}

As a source to establish other economic necessities of our DU, we mainly used a study carried out on reproduction expenses of a rural DU in Catalonia in a context of wine-growing specialization (Colomé, 2015). For clothing and footwear Colomé proposes an average annual cost for an adult man of about 30 pesetas. Using the proposed factors on age for the whole family, this implies a total of 109.2 pesetas per DU, or $21.84 * Z$ pesetas. For housing expenses, in order to pay the annual rent a peasant family would need the equivalent of about 36 workdays in the Catalan Penedès County in 1872. We considered that the average agricultural wage was around 72 pesetas (Colomé, 1996). However, at Catalan level another average has been set at around 85 pesetas (Vicedo et al., 2002). Summing up, expenses associated with the maintenance of the DU will be $21.84 * Z+85$ pesetas. Also as part of the maintenance of the DU we considered the cost of keeping and replacing the equipment of farm implements in order to use them in a sustainable manner. In this case, a study also cited by Colomé (1996) fixed the cost of amortization of farm implements in the municipality of Santa Margarida i els Monjos (Alt Penedès County) at 2.04 pesetas/ha, a value that we will be taken as a reference in our case. The annual cost of maintenance of the barrel and cellar for wine producing is estimated at 19.9 pesetas, according to Colomé (1996).

With regard to tax burdens, we consider the costs of paying the royal land, housing and livestock cadastral taxes, and the municipal ones. Regarding the seigneurial censuses paid to the Marquis de Sentmenat, although it is true that some of them continued to be paid even at that time or even later, due to their devaluation through price inflation we considered them to be anecdotal. According to the Distribution of Personal Wealth in Real Estate Ownership of 1852 in the Barcelona Province (Library of the University of Barcelona, reference 146-1-II/13), in Sentmenat the cadastral taxes paid ranged on average $15 \%$ of taxable liquid incomes estimated (with a $\mathrm{R}^{2}$ of 0.9996 ). The municipal taxes were accounted as a surcharge on this royal one, in such a way that surely ended up representing a direct tax burden of $20 \%$ of agricultural incomes calculated through the taxable liquid values set in the cadastre. So as to identify the relationship set between the types and qualities of land and the tax burden paid, we made a multiple regression analysis relating the crop surface data of the 1859 municipal land register (Amillaramiento) and the taxable liquid incomes determined by the cadastre. The correlation had a $\mathrm{R}^{2}$ value of 0.745 .

Likewise, we carried out a regression analysis on the valuation of the taxable liquid according to livestock owned. We get that a mule was computed as 34 reales of additional taxable income, a pig as 7.9, and a sheep as 1.3 (after 1869, 1 Spanish peseta $=4$ reales).

Once the most basic monetary needs are satisfied, we calculated the total contribution of the farm surplus in monetary terms. For this, we estimated the potential sources of money that came from each crop. Given the approximate value of this constraint, we decided only to contemplate the surplus of the 
main products, and not what could be obtained from the sale of minor items such as straw (which had a small value). We obtained prices mainly from the Estudio Agrícola del Vallés of 1874.

\section{References}

American Society of Agricultural Engineers (ASAE), 2000. Manure production and characteristics. Saint Joseph.

Brenes, A., Brenes, J., Pontes, M., 1978. Requerimientos nutritivos del conejo. Le Courr. Avic. 34, 117-127.

Burden, F., 2012. Practical feeding and condition scoring for donkeys and mules. Equine Vet. Educ. 24, 589-596. doi:10.1111/j.2042-3292.2011.00314.x

Cascón, J., 1918. El estiércol y la alimentacion animal. Alrededor del mundo, Madrid.

Church, D.C., 1984. Alimentos y alimentacion del ganado. Tomo II. Hemisferio sur, Buenos Aires.

Colomé, J., 2015. Pequeña explotación agrícola, reproducción de las unidades familiares campesinas y mercado de trabajo en la viticultura mediterránea del siglo XIX: el caso catalán. Rev. Hist. Económica 18, 281-307. doi:10.1017/CBO9781107415324.004

Colomé, J., 1996. L’especialització vitícola a la Catalunya del segle XIX. Universitat de Barcelona.

Cong, R.G., Ekroos, J., Smith, H.G., Brady, M. V., 2016. Optimizing intermediate ecosystem services in agriculture using rules based on landscape composition and configuration indices. Ecol. Econ. 128, 214-223. doi:10.1016/j.ecolecon.2016.05.006

Cussó, X., Garrabou, R., 2000. Alimentacio i nutricio al Vallès Oriental en les darreres dècades del segle XIX. Lauro 21, 26-34.

Farran, A., Zamora, R., Cervera, P., 2004. Tablas de composición de alimentos del CESNID. Universitat de Barcelona. McGraw-Hill, Barcelona.

Fundacion Española para el Desarrollo de la Nutrición Animal, 2010. Tablas FEDNA de composicion y valor nutritivo de alimentos para la fabricacion de piensos compuestos (3a edicion). Madrid.

Galler, C., von Haaren, C., Albert, C., 2015. Optimizing environmental measures for landscape multifunctionality: Effectiveness, efficiency and recommendations for agri-environmental programs. J. Environ. Manage. 151, 243-257. doi:10.1016/j.jenvman.2014.12.011

Garrabou, R., Planas, J., 1998. Estudio Agrícola del Vallès 1874. Impremta de Granollers, Granollers.

Garrabou, R., Pujol, J., Colomé, J., Saguer, E., 1992. Estabilidad y cambio de la explotación campesina (Cataluña, siglo XIX-XX). Prop. y Explot. campesina en la España Contemp. 15-92.

Giménez, D.M., 1994. Nutrient Requirements of Sheep and Goats. ANR-812. Montgomery.

González de Molina, M., García Ruiz, R., Guzmán, G.I., Soto, D., Infante, J., 2010. Guideline for constructing nutrient balance in historical agricultural systems (and its application to three casestudies in southern Spain) (No. 1008), DT-SEHA. Madrid.

Gootas, H.B., 1956. Composting: Sanitary disposal and reclamation of organic wastes (No. 31).

Guzmán, G.I., Aguilera, E., Soto, D., Cid, A., Infante, J., García Ruiz, R., Herrera, A., Villa, I., González de Molina, M., 2014. Methodology and conversion factors to estimate the Net Primary Productivity of historical and contemporary agro-ecosystems (No. 1407), WP-SEHA.

Harrison, M., 1975. Chayanov and the economics of the Russian Peasantry. J. Peasant Stud. 2, 389417. doi:10.1080/03066157508437947

Marco, I., Padró, R., Cattaneo, C., Caravaca, J., Tello, E., 2017. From vineyards to feedlots : A fundflow scanning of sociometabolic transitions in the. Reg. Environ. Chang. 1-13. doi:10.1007/s10113-017-1172-y

Marco, I., Padró, R., Tello, E., n.d. Labour, Nature and Exploitation: A first exploration on the relationships between Social Metabolism and Inequality in Traditional Organic Farm Systems. Forthcoming.

National Research Council, 1989. Nutrient Requirements for Horses. National Academy Press, Washington.

Olarieta, J.R., Rodríguez-Valle, F.L., Tello, E., 2008. Preserving and destroying soils, transforming landscapes: Soils and land-use changes in the Vallès County (Catalunya, Spain) 1853-2004. Land use policy 25, 474-484. doi:10.1016/j.landusepol.2007.10.005 
Roca, P., 2007. Agricultura i ramaderia en les masies del Vallès Occidental (1670-1830).

Soroa, J., 1953. Prontuario del agricultor y el ganadero, 8th ed. Dossta, Madrid.

Tscharntke, T., Tylianakis, J.M., Rand, T. a., Didham, R.K., Fahrig, L., Batáry, P., Bengtsson, J., Clough, Y., Crist, T.O., Dormann, C.F., Ewers, R.M., Fründ, J., Holt, R.D., Holzschuh, A., Klein, A.M., Kleijn, D., Kremen, C., Landis, D. a., Laurance, W., Lindenmayer, D., Scherber, C., Sodhi, N., Steffan-Dewenter, I., Thies, C., van der Putten, W.H., Westphal, C., 2012. Landscape moderation of biodiversity patterns and processes - eight hypotheses. Biol. Rev. 87, 661-685. doi:10.1111/j.1469-185X.2011.00216.x

Unitat de Producció Agrària i Ecològica, 2011. Fitxa tècnica PAE 15: Avicultura Ecològica de la Carn. Barcelona.

Vicedo, E., Colomé, J., Saguer, E., 2002. Las condiciones de reproducción económica de las unidades familiares campesinas en Cataluña a mediados del siglo XIX, in: Martínez Carrión, J.M. (Ed.), El Nivel de Vida En La España Rural, Siglos XVIII-XX. Universidad de Alicante, Alicante, pp. 321-358. 